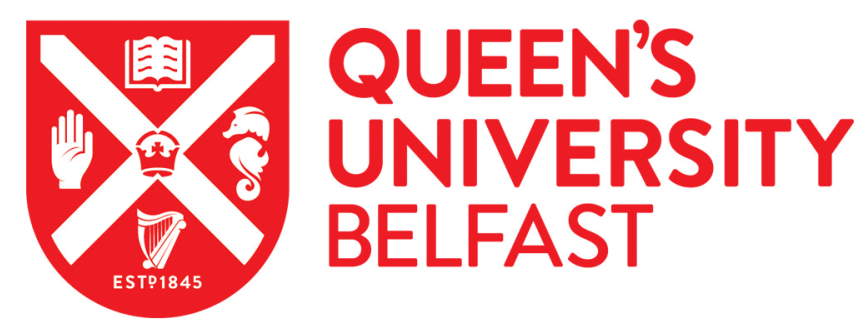

\title{
Radiocarbon Chronology of Complexes with Seima-Turbino Type Objects (Bronze Age) in Southwestern Siberia
}

Marchenko, Z. V., Svyatko, S. V., Molodin, V. I., Grishin, A. E., \& Rykun, M. P. (2017). Radiocarbon Chronology of Complexes with Seima-Turbino Type Objects (Bronze Age) in Southwestern Siberia. Radiocarbon, 59(5), 1381-1397. https://doi.org/10.1017/RDC.2017.24

Published in:

Radiocarbon

Document Version:

Peer reviewed version

Queen's University Belfast - Research Portal:

Link to publication record in Queen's University Belfast Research Portal

Publisher rights

Copyright 2017 Cambridge University Press. This work is made available online in accordance with the publisher's policies. Please refer to any applicable terms of use of the publisher.

\section{General rights}

Copyright for the publications made accessible via the Queen's University Belfast Research Portal is retained by the author(s) and / or other copyright owners and it is a condition of accessing these publications that users recognise and abide by the legal requirements associated with these rights.

Take down policy

The Research Portal is Queen's institutional repository that provides access to Queen's research output. Every effort has been made to ensure that content in the Research Portal does not infringe any person's rights, or applicable UK laws. If you discover content in the Research Portal that you believe breaches copyright or violates any law, please contact openaccess@qub.ac.uk. 
RADIOCARBON

\section{罒・圂 CAMBRIDGE

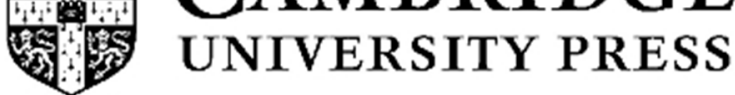

\section{RADIOCARBON CHRONOLOGY OF SEIMA-TURBINO TYPE OBJECTS (LATE BRONZE AGE) IN THE SOUTH OF WESTERN SIBERIA}

\begin{tabular}{|r|l|}
\hline Journal: & Radiocarbon \\
\hline Manuscript ID & RDC-CONF-2016-0158 \\
\hline Manuscript Type: & 2016 Radiocarbon and Archaeology Conference Paper \\
\hline Date Submitted by the Author: & 30 -Sep-2016 \\
\hline Complete List of Authors: & $\begin{array}{l}\text { Marchenko, Zhanna; Institute of Archaeology and Ethnography SB RAS, } \\
\text { Archaeology of Palaeometall } \\
\text { Svyatko, Svetlana; Queen's University Belfast, 14CHRONO Centre for } \\
\text { Climate, the Environment, and Chronology } \\
\text { Molodin, Vyacheslav; Institut arkheologii I etnografii SO RAN, Archaeology } \\
\text { of Palaeometall Institut arkheologii I etnografii SO RAN, Archaeology of } \\
\text { Grishin, Artem; Institu } \\
\text { Palaeometall } \\
\text { Rykun, Marina; Tomsk State University, Cabinet of Anthropology }\end{array}$ \\
\hline Keywords: & Radiocarbon dating \\
\hline \multicolumn{2}{|c}{} \\
\hline
\end{tabular}




\title{
RADIOCARBON CHRONOLOGY OF SEIMA-TURBINO TYPE OBJECTS (LATE BRONZE AGE) IN THE SOUTH OF WESTERN SIBERIA
}

\author{
ZV Marchenko ${ }^{1,2,3}$, SV Svyatko ${ }^{4}$, VI Molodin ${ }^{1}$, AE Grishin $^{1}$, MA Rykun ${ }^{5}$ \\ ${ }^{1}$ Institute of Archaeology and Ethnography, Siberian Branch of the Russian Academy of \\ Sciences, Novosibirsk 630090, RUSSIA \\ ${ }^{2}$ Corresponding author.Email: afrika_77@mail.ru \\ ${ }^{3}$ Novosibirsk State University, Novosibirsk 630090, RUSSIA \\ ${ }^{4} 14$ CHRONO Centre for Climate, the Environment, and Chronology, Queen's University Belfast, \\ Belfast BT7 1NN, Northern Ireland, UK \\ ${ }^{5}$ Tomsk State University, Tomsk 634050, RUSSIA
}

\begin{abstract}
This paper discusses the chronology of the burial grounds containing specific Seima-Turbino type bronze weaponry (spears, knifes and celts). The "transcultural" Seima-Turbino phenomenon concerns with the wide distribution of specific objects found within the sites of different Late Bronze Age cultures in Eurasia, not immediately related between each other. The majority of the Seima-Turbino objects represent occasional findings, and rarely are they recovered from burial grounds. Here, we present the new set of ${ }^{14} \mathrm{C}$ dates from cemeteries of Western Siberia (including the key Asian site Rostovka with the largest number of graves with Seima-Turbino objects), currently the most extensive for the Seima-Turbino complexes.
\end{abstract}

The resulting radiocarbon chronology for the Western Siberian sites $\left(22^{\text {nd }}-20^{\text {th }}\right.$ c. cal BC) is older than the existing chronology based on typological analysis $\left(16^{\text {th }}-15^{\text {th }}\right.$ c. BC) and than that some earlier radiocarbon dates for the Seima-Turbino sites in Eastern Europe.

Another important aspect of this work is ${ }^{14} \mathrm{C}$ dating of specific bronze objects - daggers with figured handles, which some researchers relate to the Seima-Turbino type objects. These items are mostly represented by occasional finds in Central Asia, however, in Western Siberia these have been recovered from burials too. The radiocarbon dating attributes these daggers to the end of the $3^{\text {rd }}$ mil. cal BC suggesting their similar timing period as that of the Seima-Turbino objects.

Further research into freshwater reservoir offsets in the region is essential for the more reliable reconstruction of chronology of the Seima-Turbino phenomenon and the daggers with figured handles.

\section{INTRODUCTION}

The Seima-Turbino (ST) transcultural phenomenon is a distinctive and enigmatic occurrence in the Late Bronze Age archaeology of Eurasia, and one of the key research issues for decades [e.g. Chernych 1992]. It refers to the emergence and wide and rapid distribution of specific bronze objects in Siberia and Eastern Europe, which mainly represent weaponry items - spears, celts and knifes, often decorated by geometric figures or carrying figured tops on knife handles (Figure 1 and 2). The most common shape of the tops is horse (Figure 2, items 1 and 2), and in one case - a man and a horse (Figure 2, item 1). 


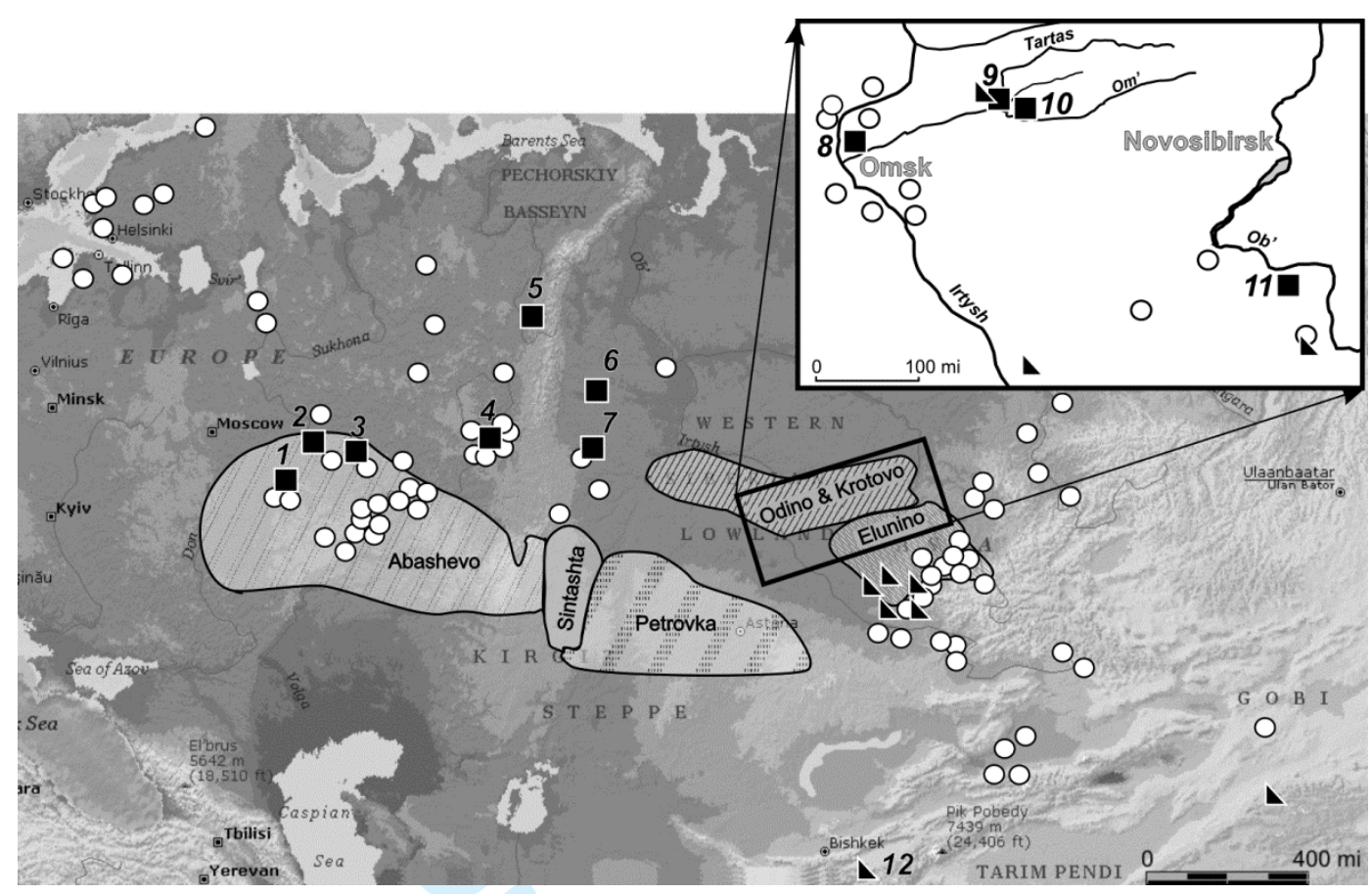

Figure 1. Map showing the distribution of the Seima-Turbino objects (circles for occasional and single finds and rectangles for funeral and ritual-funeral complexes) and daggers with figure handles (triangles indicate complexes and occasional finds) in Eurasia. Seima-Turbino sites: 1 - Seima, 2 - Reshnoe, 3 - Ust'-Vetluga, 4 - Pepkinskii Kurgan and Turbino, 5 - Kaninskaya cave, 6-Satyga 16, 7 - Shaitanskoe 2, 8- Rostovka, 9 - Tartas 1, Sopka 2/4B and Sopka 2/4C, 10 - Preobrazhenka 6,11-Elunino 1 and Teleutskii Vzvoz 1. Complexes containing daggers with figure handles: 9 - burial ground Sopka 2/4B, 12 - the Second Karakol Hoard. Map sources: Chernykh 2015, Chlenova 1976, Alekhin and Vladimirov, 1984, Molodin 1983, 1993, Samashev and Zumabekova, 1993, Grushin et al. 2006, Kiryushin et al. 2006, Molodin et al. 2007, 2011, Kovalev 2013. Map adapted from Microsoft Encarta 2006.

In Eastern Europe, the main ST type findings have been made in the Volga-Ural region (Seima, Reshnoe and Ust'-Vetluga sites), forest zone of Cis-Ural (Turbino and Kaninskaya Cave) and Trans-Urals (Satyga 16 and Shaitanskoe 2; Figure 1). In general, these mostly represent ritualfuneral and funeral sites. In Western Siberia, the main sites are located in the Ob-Irtysh foreststeppes (Rostovka, Preobrazhenka 6, Sopka 2/4C, Vengerovo 2) and in the Upper Ob River region (Elunino 1; Chernykh and Kuzminykh 1987, Kiryushin 1987, Chernykh 2015). The majority of the Western Siberian sites are necropoleis and in one case a settlement (Vengerovo 2; Molodin et al. 2015). Besides, a vast number of ST bronze objects are represented by occasional finds recovered as widely as from Baltic Sea coast to Southern Siberia (Minusinsk Basin). Notably, among the Western Siberian materials, not only bronze objects themselves, but the associated casting molds have been found indicating the local production of the objects. The findings of weaponry (spears, knifes, axes) and bone and horn armor plates in burials suggest the military lifestyle of the population which left the objects. The image of a horse in the ST bronze art characterizes it as a domesticated animal and indicates its important role in human life.

Seima-Turbino complexes have been investigated for more than a century, from collecting isolated unique objects, discovery of distinctive and original ritual-funeral sites, to considering them as the Eurasian "transcultural phenomenon" (Chernykh and Kuzminykh 1987 p. 84-105). Until the present, the main issues of the ST problematics have concerned not only the initial provenance of the bronze objects, identification of the people who produced them and their 
relationships with other populations of forest and forest-steppe zone of Eurasia, but also chronology and means of distribution of the items. Comparative analysis of metal objects in various archaeological sites allowed attributing considerable part of complexes of Middle and Lower Volga region, Southern Urals and Trans-Urals to the "Seima chronological horizon" including Srubnaya and Abashevo Cultures (Chernykh 1970, Figure 67). The major concentration of the ST type objects has been found in the Volga-Ural region. The Abashevo sites either preceded or coexisted with the "Seima chronological horizon" (third quarter of the $2^{\text {nd }}$ mil. BC, ibid, p. 103). However, the thin-wall-casting technology of the ST type bronze objects makes their principle difference from rather rough Abashevo (or "common Eurasian" by Chernykh 1970) casting and the later forging technology, which does not allow considering South Urals and Cis-Urals as the area of production of these items. The spectrum analysis of the ST bronze objects suggests Sayano-Altai Mountains as a region of provenance of raw materials (tin bronze) used. Therefore, until recently, it has been assumed that western foothills of SayanoAltai Mountains were the place of origin of the ST transcultural phenomenon (Chernykh 1970). However, the increasing number of ST finds in Western Siberia and Central Asia allows expanding the presumable place of the initial impulse onto eastern and south-eastern foothills of Altai (Chernykh 2015).
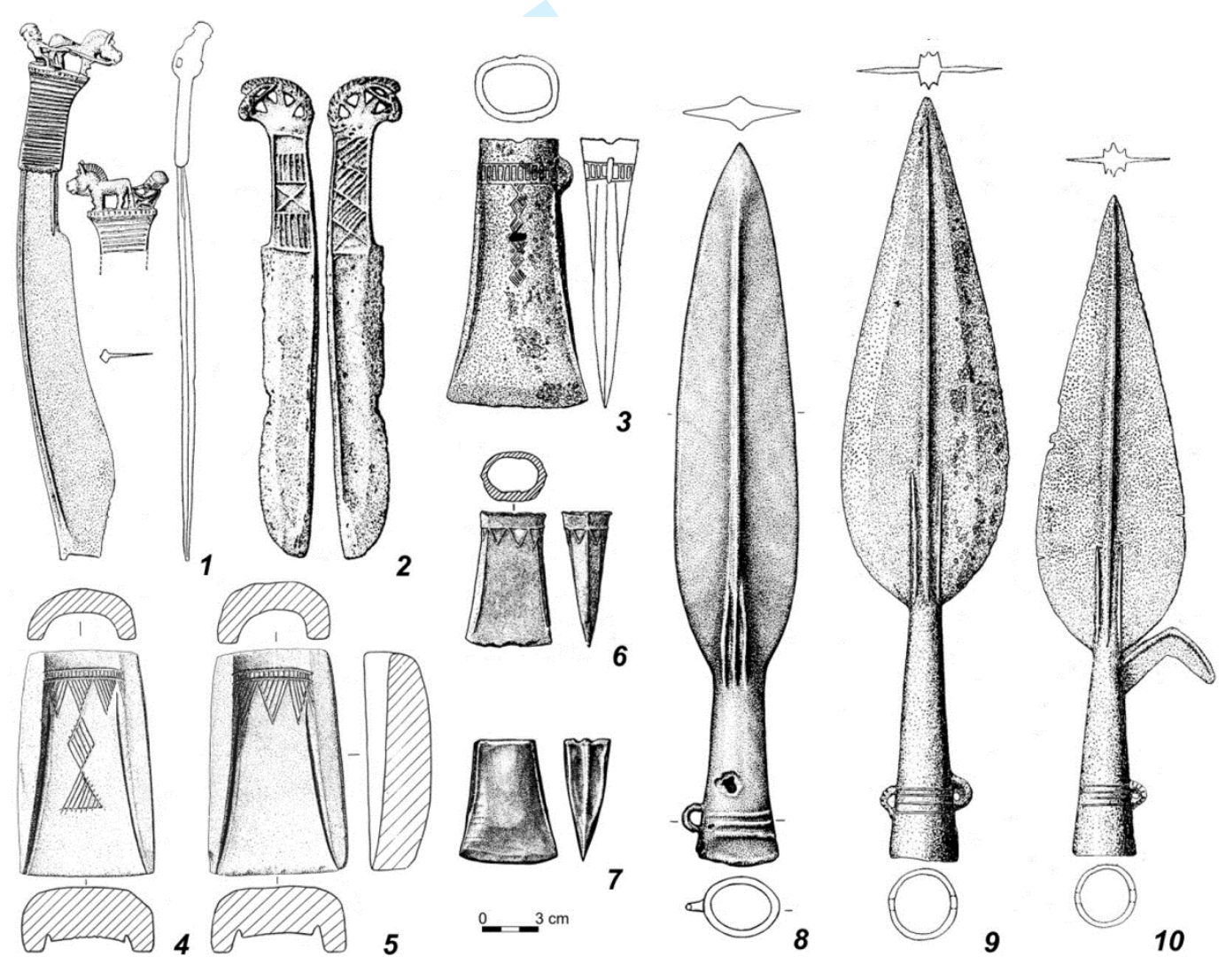

Figure 2. Seima-Turbino objects (4, 5 - stone, other - bronze) from the burial grounds of the south of Western Siberia. 1, 3, 9, 10 - Rostovka (Matyushchenko and Sinitsyna 1988); 2 - Elunino 1 (Kiryushin 1987); 4-6 - Sopka 2/4C (Molodin 1983); 7 - Tartas 1 (Molodin et al. 2011), 8 - Preobrazhenka 6 (Molodin et al. 2007).

For a long time, Seima-Turbino objects were dated using the Balkan (Borodino Hoard, Moldova Republic) and Chinese analogies (Anyang complexes; e.g. Chernykh 1970). The comparative analysis of these complexes suggested $16^{\text {th }}-15^{\text {th }} \mathrm{c}$. BC as the timing of their existence (Chernykh 
and Kuzminykh 1987, Chernykh 1992). The appearance of the first sparse radiocarbon dates from burial materials did not resolve the chronology issue, as they showed earlier age of complexes (Kiryushin 1987) than comparative typological analysis of the bronze objects.

Here, we present the new set of radiocarbon $\left({ }^{14} \mathrm{C}\right)$ dates from human remains originating from burials containing ST type objects in the south of Western Siberia. An important aspect of this study that burials with the ST type objects were dated directly, including is the key site of Rostovka. Such an approach will significantly increase the precision of the ST chronology, as previously in many cases ${ }^{14} \mathrm{C}$ dates were produced from burials which did not contain bronze items themselves (Kiryushin et al. 2003, Trufanov 2011). Comparison of the new and existing ${ }^{14} \mathrm{C}$ dates will allow defining the chronological position of Western Siberian sites among ST complexes and other archaeological cultures of forest and forest-steppe zone of Eurasia.

Another aspect of this work is ${ }^{14} \mathrm{C}$ dating of bronze figure-handled daggers (Figure 3). Similar to the ST bronzes, these daggers are also characterised by an advanced level of metalwork, and some have suggested that they are possibly related to the ST phenomenon (Molodin 1993, Parzinger 2000). These items, same as the ST objects, mostly represent occasional findings from Central Asia (East Kazakhstan, Altai, Xinjiang) and south of Western Siberia (Chlenova 1976, Aleshin and Vladimirov 1984, Molodin 1993, Samashev and Zumabekova 1993, Grushin et al. 2006, 2009, Kiryushin et al. 2006, Kovalev 2013). As to closed complexes - to date, only two are known to have contained the daggers. These are the hoard of five daggers from Eastern Kyrgyzstan (the Second Karakol's hoard, Karakol village; Vinnik and Kuz'mina 1981) and burials 425, 427, 443 of Sopka 2/4B site (Baraba-forest-steppe, south of Western Siberia; Molodin 1993). Earlier, the chronology of these daggers was based on their stylistic comparison with metal objects from various Bronze Age Siberian archaeological cultures (Elunino, Krotovo, Karasuk) and also with the ST metal complex, and was attributed to the first half of the $2^{\text {nd }}$ mil. BC (Molodin 1993, Parzinger 2000) or the end of the $2^{\text {nd }}$ mil. BC (Chlenova 1976, Kiryushin and Grushin 2009, Papin and Fedoruk 2009, Kovtun 2013). 


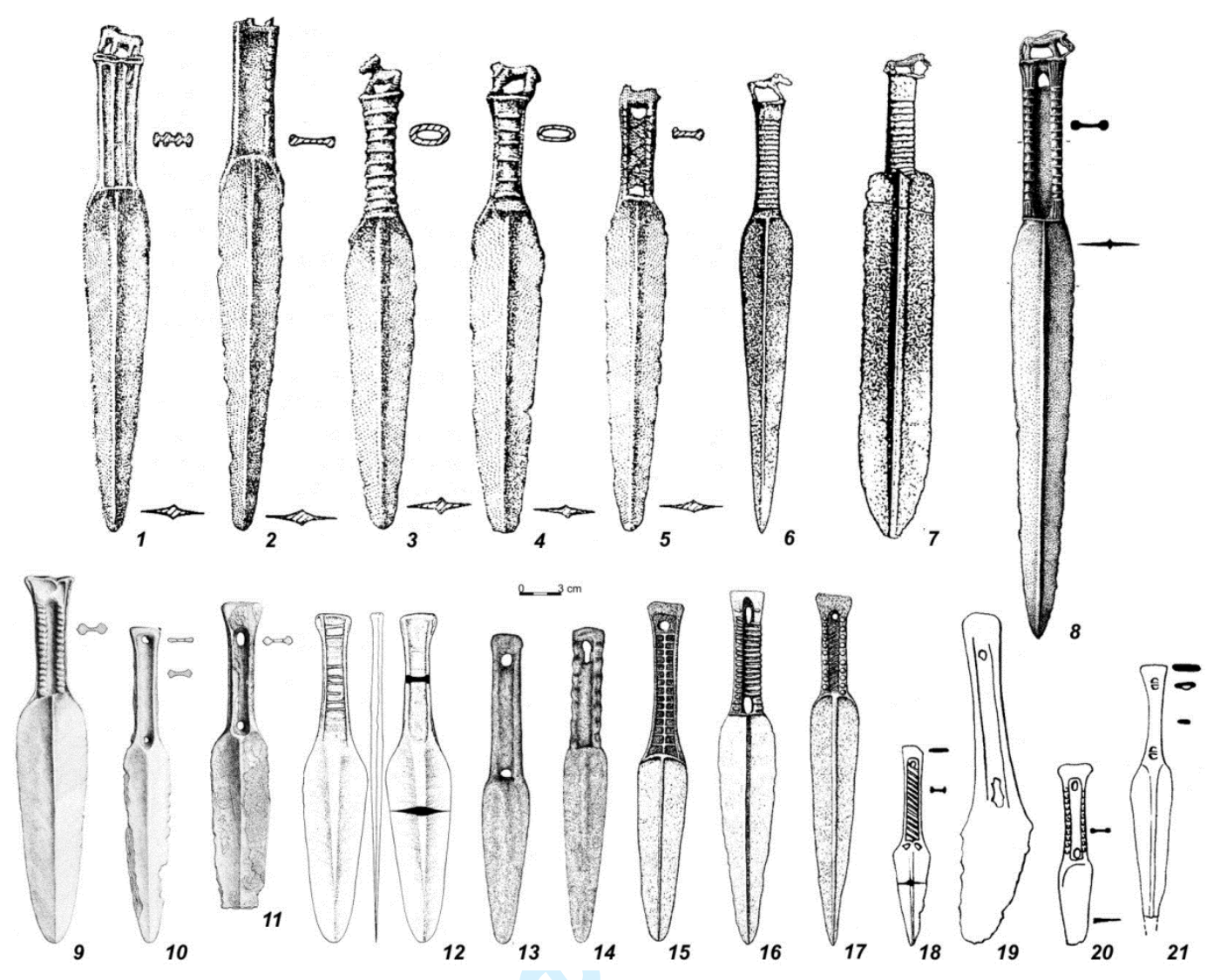

Figure 3. Bronze daggers with figure handles from Sopka 2/4B burial ground and their analogies. 1-5 - the Second Karakol Hoard (Vinnik and Kuz'mina 1981), 9-11 - Sopka 2/4B (Molodin 1993), other - occasional finds. 6, 7 Eastern Kazakhstan (Samashev and Zumabekova, 1993), 8 - Altai (Kiryushin et al. 2006), 12 - Upper Irtysh River basin (Grushin et al. 2006), 13, 14 - province Gansu (Kovalev 2013), 15 - Southern Siberia (Chlenova 1976), 16 Altai (Alekhin and Vladimirov 1984), 17 - Altai (Chlenova 1976), 18, 21 - Kazakhstan (Chlenova 1976), 19Kazakhstan (Chernikov 1960), 20 - Altai or Kazakhstan (Chlenova 1976). 15-21 are without scale.

\section{ARCHAEOLOGICAL SITES}

Burial materials from the south of Western Siberia have been used for the chronological analysis of Seima-Turbino type objects and bronze figure-handled daggers. These included Rostovka one of the key sites of the ST problematics, located in Middle Irtysh River basin, and also individual graves containing ST items from four Bronze Age necropoleis of Baraba forest-steppe (Sopka 2/4B, Sopka 2/4C, and Tartas 1 sites; Figure 1).

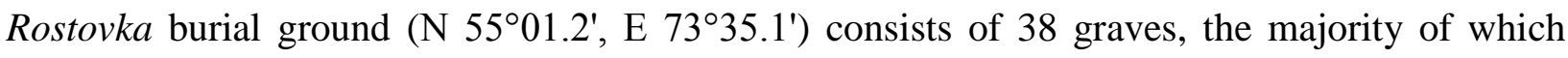
contain bronze ST items (celts, spears, knifes; Figure 2, items 1, 3, 9, 10; Matyushchenko and Sinitsyna 1988, Chernykh and Kuzminykh 1987, Chernykh 1992). The prevailing number of burials shows traces of disturbance in ancient times, and in some cases - traces of fire, including calcined ground, charcoal and cremated bones. Bronze objects have been found inside burials, or placed in compact assemblages on the ground beside graves. The stone molds for casting bronze objects were also placed in graves or next to them. Apart from bronze weaponry, stone spearheads and horn armor plates have been found.

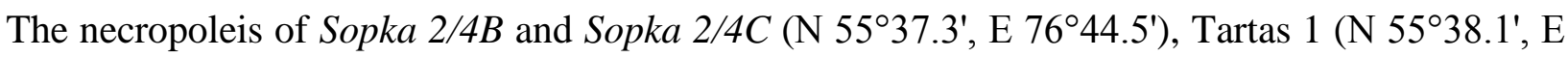

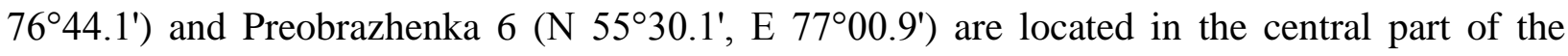


Baraba forest-steppe (Molodin 1985, 2001, 2012, Molodin et al. 2003, 2007, 2011, 2015). Sopka $2 / 4 B$ represents a group of the Krotovo Culture graves within the Sopka 2 necropolis in total consisting of more than 600 Neolithic to Medieval burials (Molodin 1985, 2001, 2012). Burial 427 contained the casting mold for the ST type bronze spear. The grave was made among the earlier Krotovo Culture burials (and therefore was considered synchronous to them for a long time; Molodin 1985), and carried traces of destruction. Radiocarbon dating attributed the main part of the Krotovo Sopka 2/4B to the first half of the $3^{\text {rd }}$ mil. BC (Molodin et al. 2010). The burial ground Sopka 2/4C appears as planigraphically isolated group of three graves $(282,594$ and 623) within Sopka 2 site. Burial 282 represents the so-called "grave of a caster" which contains objects related to casting (stone casting molds and clay melting pots) and bronze items themselves (celt; Figure 2, items 4-6; Molodin 1983). The nearby graves 594 and 623 did not contain similar objects but were characterized by similar burial practice atypical for the Bronze Age - the deceased were buried on their back with knees bent up.

The Tartas 1 necropolis is located $1.5 \mathrm{~km}$ north-east from Sopka 2 (Molodin et al. 2003, 2011). The core of the site is Bronze Age burials, the majority of which date to the first part of the $2^{\text {nd }}$ mil. cal BC (Molodin et al. 2012). Burial 487 contained bronze celt (Figure 2, item 7; Molodin et al. 2011) and the remains of 20-25 years old woman, positioned similar to burials of Sopka 2/4C - on the back with knees bent up.

Bronze figure-handled daggers (Figure 3, items 9-11) were found in burials 420, 425 and 443 of Sopka 2/4B (Molodin 1993). Currently these are the only cases when daggers of this type come from burials. Graves 420 and 425, and also 427 containing ST type object, were located among the earlier burials of the Krotovo Culture at the Sopka 2/4B and did not appear to stratigraphically overlap them. Burial 425 had somewhat separated position, while burial 420 was in line with other three graves, the cultural attribution of which cannot be determined due to significant destruction. Burial 443 also located among earlier burials of Krotovo Culture.

\section{MATERIALS AND METHODS}

In total, 23 samples from 5 sites of the Baraba forest-steppe (Sopka 2/4B, Sopka 2/4C, Tartas 1 and Staryi Tartas) and the Middle Irtysh River basin (Rostovka) were used for the radiocarbon analysis (Table 1). Among them, 15 samples derive from the Seima-Turbino complexes (seven burials of Rostovka, burial 427 of Sopka 2/4B, burial 282 of Sopka 2/4C and burial 487 of Tartas 1). One sample, discovered near Staryi Tartas settlement on the Om River, not far from Tartas 1 and Sopka 2, represents the occasional finding of bronze ST type celt. This object likely came from the coast scree of the Bronze Age cultural layer which is now overlaid by modern agricultural buildings. For radiocarbon dating, the wooden handle from the sleeve celt was used, as well as bones of two humans from burials 420 and 425 of Sopka 2/4B which contained bronze figure-handled daggers. 
Table 1. Radiocarbon dates, calibrated ages and stable isotope values for the Seima-Turbino complexes of Eurasia (from current and previous research). Sk. - skeletal. ${ }^{1}$ Marchenko et al., 2015, ${ }^{2}$ Kuryushin et al. 2003, ${ }^{3}$ Kiryushin et al. 1987, ${ }^{4}$ Hanks et al. 2007, ${ }^{5}$ Yunger and Karpelan 2005, ${ }^{6}$ Kuznetsov 2003

\begin{tabular}{|c|c|c|c|c|c|c|c|c|c|}
\hline Site & Burial & Lab. Code & ${ }^{14} \mathrm{C}, \mathrm{BP}$ & Material & $\begin{array}{l}\text { Cal. age, } \\
\text { BC }(2 \sigma)\end{array}$ & $\begin{array}{c}\delta^{13} \mathrm{C} \\
\% 0\end{array}$ & $\begin{array}{c}\delta^{15} \mathrm{~N}, \\
\%\end{array}$ & $\begin{array}{c}\mathrm{C}: \mathrm{N}_{\mathrm{a}} \\
\mathrm{t}\end{array}$ & $\begin{array}{c}\% \\
\text { colla } \\
\text { gen }\end{array}$ \\
\hline \multirow[t]{11}{*}{ Rostovka } & 5 & UBA-31379 & $3508 \pm 40$ & $\begin{array}{l}\text { human bone } \\
\text { (craneo) }\end{array}$ & $1938-1700$ & -20.6 & 13.6 & 3.24 & 4.8 \\
\hline & 5 & UBA-31396 & $3682 \pm 40$ & human tooth (uM3) & $2197-1951$ & -20.0 & 14.5 & 3.18 & 11.3 \\
\hline & $\begin{array}{c}8, \text { sk. } \\
4\end{array}$ & UBA-31381 & $3709 \pm 34$ & $\begin{array}{l}\text { human bone } \\
\text { (vertebra) }\end{array}$ & $2202-1983$ & -21.1 & 14.7 & 3.21 & 5.4 \\
\hline & $\begin{array}{c}8, \text { sk. } \\
4\end{array}$ & UBA-31398 & $3708 \pm 30$ & $\begin{array}{l}\text { human tooth (I } \\
\text { M3) }\end{array}$ & $2200-2023$ & -19.0 & 16.8 & 3.20 & 10.6 \\
\hline & 23 & UBA-29311 & $3822 \pm 32$ & $\begin{array}{l}\text { human bone } \\
\text { (temporal) }\end{array}$ & $2455-2144$ & -20.8 & 13.5 & 3.15 & 4.7 \\
\hline & 24 & UBA-29313 & $3564 \pm 38$ & human tooth (M2) & 2054-1774 & -20.5 & 12.7 & 3.22 & 14.8 \\
\hline & 27 & UBA-31383 & $3655 \pm 40$ & $\begin{array}{l}\text { human bone } \\
\text { (craneo) }\end{array}$ & 2141-1918 & -20.8 & 14.0 & 3.20 & 6.7 \\
\hline & 27 & UBA-31399 & $3635 \pm 40$ & human tooth (IM3) & $2135-1896$ & -20.1 & 13.1 & 3.20 & 12.5 \\
\hline & 33 & UBA-31382 & $3640 \pm 31$ & $\begin{array}{l}\text { human bone } \\
\text { (craneo) }\end{array}$ & 2133-1919 & -21.2 & 14.6 & 3.21 & 10.7 \\
\hline & 34 & UBA-31380 & $3646 \pm 39$ & $\begin{array}{l}\text { human bone } \\
\text { (vertebra) }\end{array}$ & 2137-1919 & -20.4 & 13.7 & 3.19 & 7.5 \\
\hline & 34 & UBA-31397 & $4066 \pm 50$ & $\begin{array}{l}\text { human tooth (ur } \\
\text { M3) }\end{array}$ & $2862-2473$ & -20.8 & 14.1 & 3.19 & 9.2 \\
\hline Staryi Tartas & - & UBA-27417 & $3834 \pm 31$ & wood & $2456-2200$ & - & - & - & - \\
\hline \multirow[t]{5}{*}{ Sopka 2/4B } & 420 & UBA-27424 & $3917 \pm 38$ & human bone & $2559-2289$ & -19.7 & 14.3 & 3.17 & 14.9 \\
\hline & 425 & UBA-25026 & $3784 \pm 40$ & human bone & $2388-2042$ & -22.4 & 15.4 & 3.20 & 15.8 \\
\hline & 427 & UBA-25027 & $3787 \pm 31$ & human bone & $2335-2063$ & -21.1 & 13.1 & 3.15 & 17.7 \\
\hline & 464 & SOAN-8269 & $3730 \pm 35$ & $\begin{array}{l}\text { human bone } \\
\text { (Femur Dx) }\end{array}$ & $2276-2028$ & - & - & - & - \\
\hline & 464 & UBA-29748 & $3643 \pm 57$ & Ovis bone & $2198-1883$ & -19.4 & 6.7 & 3.27 & 4.6 \\
\hline \multirow[t]{4}{*}{ Sopka $2 / 4 \mathrm{C}$} & 282 & SOAN-7725 & $3805 \pm 75$ & $\begin{array}{l}\text { human bone (Tibia } \\
\text { Sin, Femur Sin) }\end{array}$ & $2467-2036$ & - & - & - & - \\
\hline & 594 & SOAN-7718 & $3850 \pm 105$ & $\begin{array}{l}\text { human bone } \\
\text { (Femur Sin) }\end{array}$ & 2581-1980 & - & - & - & - \\
\hline & 594 & UBA-25028 & $3712 \pm 32$ & human bone & $2202-2024$ & -21.4 & 14.1 & 3.19 & 25.2 \\
\hline & 623 & UBA-25029 & $3661 \pm 34$ & human bone & $2139-1943$ & -22.3 & 14.2 & 3.29 & 12.7 \\
\hline \multirow[t]{2}{*}{ Tartas 1} & 487 & UBA-27422 & $3811 \pm 61$ & human bone & $2464-2050$ & -20.7 & 13.1 & 3.15 & 12.1 \\
\hline & 487 & SOAN-8703 & $3935 \pm 85$ & $\begin{array}{c}\text { human bone } \\
\text { (Femur Sin, Femur } \\
\text { Dx) }\end{array}$ & $2836-2145$ & - & - & - & - \\
\hline Preobrazhenka 6 & 24 & UBA-25804 ${ }^{1}$ & $3797 \pm 29$ & human bone & $2336-2138$ & -20.7 & 13.7 & 3.21 & 2.2 \\
\hline \multirow{4}{*}{$\begin{array}{c}\text { Teleutskii Vzvoz } \\
1\end{array}$} & 10 & SOAN-4153 ${ }^{2}$ & $3690 \pm 40$ & charocoal & $2199-1960$ & - & - & - & - \\
\hline & 12 & SOAN-4154 ${ }^{2}$ & $3650 \pm 75$ & charocoal & $2278-1777$ & - & - & - & - \\
\hline & 32 & SOAN-4369 & $3610 \pm 35$ & charocoal & $2120-1885$ & - & - & - & - \\
\hline & 34 & SOAN $-4370^{2}$ & $3670 \pm 40$ & charocoal & $2195-1939$ & - & - & - & - \\
\hline Elunino 1 & 2 & SOAN- $1893^{3}$ & $3560 \pm 30$ & charocoal & $2016-1775$ & - & - & - & - \\
\hline Satyga 16 & 39 & OxA-12529 & $3655 \pm 29$ & human bone & $2135-1944$ & - & - & - & - \\
\hline \multirow[t]{3}{*}{ Ust-Vetluga } & 8 & Hela- $929^{5}$ & $3545 \pm 50$ & wood & $2023-1747$ & - & - & - & - \\
\hline & 10 & Hela- $966^{5}$ & $3395 \pm 35$ & wood & $1862-1614$ & - & - & - & - \\
\hline & 12 & Hela- $928^{5}$ & $3400 \pm 50$ & wood & $1879-1560$ & - & - & - & - \\
\hline $\begin{array}{l}\text { Pepkinskii } \\
\text { Kurgan }\end{array}$ & 2 & Ki-7665 & $3850 \pm 95$ & human bone & $2570-2035$ & - & - & - & - \\
\hline
\end{tabular}


Furthermore, we analysed five samples from Sopka 2/4B and 2/4C burials, not containing ST objects themselves but being strictly synchronous to the burials containing ST artefacts. These were used, firstly, to assess the possible influence of the freshwater reservoir effect (FRE) on the ${ }^{14} \mathrm{C}$ dates and, secondly, to increase the accuracy of the chronology of the ST complexes radiocarbon dates. Regarding the latter, the samples from burials 594 and 623 of Sopka 2/4C, synchronous to burial 282, were dated. To investigate the presence of the freshwater reservoir effect, we dated associated human and herbivore bones from Sopka 2/4B burial 464, and bone and tooth samples of four individuals from Rostovka. For the grave 594 of Sopka 2/4C and grave 487 of Tartas 1 the samples from same skeleton were dated in different laboratories.

For the analysis of chronology of the ST complexes in Baraba forest-steppe, published ${ }^{14} \mathrm{C}$ date from burial 24 of Preobrazhenka 6 site was also engaged (UBA-25804; Marchenko et al. 2015).

The dates were produced in two laboratories $-{ }^{14} \mathrm{CHRONO}$ Centre for Climate, the Environment and Chronology of the Queen's University Belfast ( $n=19$, lab code UBA) using accelerator mass spectrometry (AMS), and the Institute of Geology and Mineralogy of the Siberian Branch of the Russian Academy of Sciences (Novosibirsk; n=4, lab code SOAN) using liquid scintillation counting (LSC). Calibration was performed using OxCal v 4.2.4 software (Bronk Ramsey 1995; 2001) and the IntCal13 curve (Reimer et al. 2013; Figure 4).

For comparative analysis, the radiocarbon dates from the cemeteries of the Upper Ob River basin (Teleutskii Vzvoz 1 and Elunino 1), Trans-Ural forest zone (Satyga 16) and Middle Volga River basin forest-steppe (Ust'-Vetluga and Pepkinskii Kurgan) belonging to the Elunino $\left(21^{\text {nd }}-17^{\text {th }} \mathrm{c}\right.$. cal BC; Kiryushin et al. 2003) and Abashevo $\left(23^{\text {rd }}-19 / 18^{\text {th }}\right.$ c. cal BC; Chernykh and Orlovskaya 2013, Molodin et al. 2014, Shishlina et al. 2015) Cultures were used (Table 1, Figure 4). The dates were obtained from charcoal (Teleutskii Vzvoz 1 and Elunino 1), wood (Ust'-Vetluga) and in one case human bone samples (Satyga 16). The ${ }^{14} \mathrm{C}$ date from the Elunino 1 necropolis derives from the Elunino Culture burial which contained the ST type knife with figured handle and horse head on the top (Figure 2, item 2; Kiryushin 1987). The cemetery of Teleutskii Vzvoz 1 did not contain ST type objects, however, the overall assemblage of artefacts and burial practice were identical to that of Elunino 1. Furthermore, according to some researchers (Kiryushin et al. 2003) the bronze leaf-shaped ornamented arrowhead from the Teleutskii Vzvoz 1 grave is close to the ST metallurgical tradition. The metal complex of the Satyga 16 cemetery is not numerous or diverse and is mainly presented by common bronze knives; only remains of clay casting molds recovered from the site can be characterized as ST type objects (Trufanov 2011, p. 30-32). However, this site is considered to belong to the ST type (ibid., p. 60-85). Radiocarbon date was obtained from burial 39 which did not contain bronze objects or items associated with metallurgy.

Radiocarbon dates from the Abashevo Culture sites are important for establishing the chronology of the Seima-Turbino complexes, as ST type objects have been repeatedly found in the Abashevo sites of Middle Volga River basin suggesting their chronological similarity (Solovyov 2003, 2013, Bolshov 2012). The Ust'-Vetluga necropolis combines at least two metallurgical traditions - the local Abashevo and the external Seima-Turbino (Solovyov 2013). The radiocarbon dates were obtained from wooden handles of the ST bronze objects (Yunger and Karpelan 2005). 
From the Abashevo Culture, the ${ }^{14} \mathrm{C}$ date of Pepkinskii Kurgan grave 2 was also used (Middle Volga River basin; Kuznetsov 2003). This grave is a collective burial of 27 adult men with the signs of violent death - the majority of individuals were hit by stone arrowheads most similar to materials of the Turbino cemetery, one of the main sites related to the Seima-Turbino phenomenon (Khalikov et al. 1966).

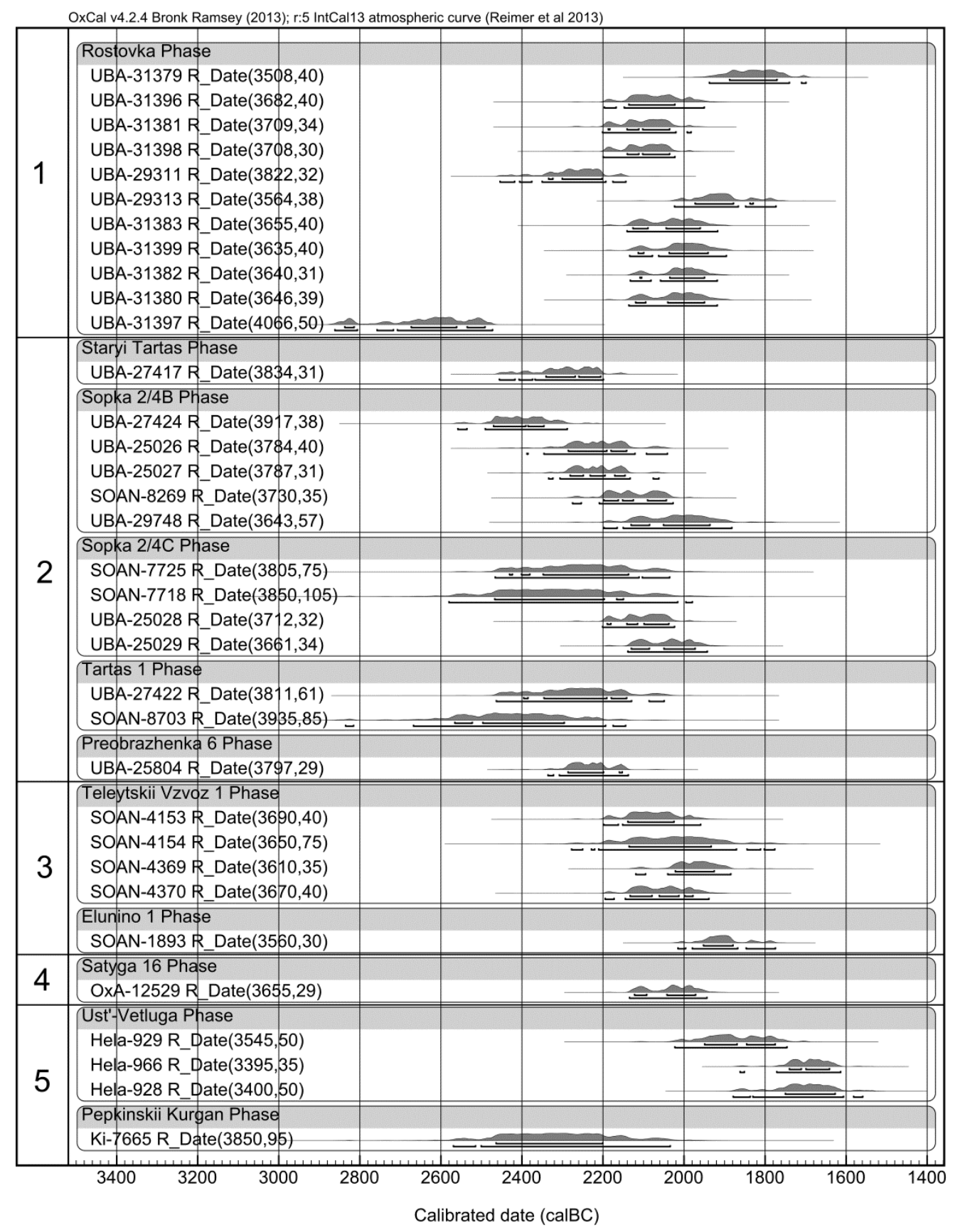

Figure 4. Plotted calibrated radiocarbon dates (from current and published research - see Table 1) of the SeimaTurbino sites: 1- Middle Irtysh River basin, 2 - Baraba forest-steppe, 3 - Upper Ob River basin, 4 - Trans-Urals, 5 Middle Volga River basin.

\section{RESULTS AND DISCUSSION}

Overview of the results

Where the data was available, the analyzed bone samples demonstrated excellent collagen preservation with yields ranging between 2.2-25.2\% (van Klinken 1999; Table 1). The C: $\mathrm{N}_{\text {at }}$ 
ratio of the samples varied between 3.2-3.3, which is also within the accepted range characterizing well-preserved collagen (DeNiro 1985).

The ${ }^{14} \mathrm{C}$ dates of burials with the ST type objects from the Baraba forest-steppe and the Middle Irtysh River basin show a wide chronological interval of $29^{\text {th }}-20^{\text {th }}$ c. cal BC (Table 1, Figure 4). Eleven ${ }^{14} \mathrm{C}$ dates from human tooth and bone samples from Rostovka appear the most homogenous - except the date of UBA-31397, these attribute to the end of the $3^{\text {rd }}$ mil. BC $\left(22^{\text {nd }}\right.$ $20^{\text {th }}$ c. cal BC). The date from burial 5 (UBA-31379) appears younger $-20^{\text {th }}-18^{\text {th }} \mathrm{c}$. cal BC. The other burials with the ST objects (Sopka 2/4B, Sopka 2/4C, Preobrazhenka 6 and Tartas 1) from Baraba forest-steppe (Ob-Irtysh region) have wider chronological intervals - from the beginning to the end of $3^{\text {rd }}$ mil. BC or $25^{\text {th }}-19^{\text {th }}$ c. cal BC if to exclude dates SOAN-8703 and SOAN-7718 with large standard deviations of more than $\pm 85 \mathrm{yrs}$. The date UBA-27417 from wooden handle of an axe appears earlier $\left(25^{\text {th }}-23^{\text {rd }}\right.$ c. cal BC) than those from human remains of Rostovka and the Baraba burial grounds, which is possible the result of the "old wood effect".

\section{Radiocarbon chronology and freshwater reservoir effects}

Recently, a special consideration has been given to the presence of the freshwater reservoir effects in the Eurasian Steppes and Siberia, and their influence on particular radiocarbon dates from human and some faunal samples, as well as entire chronologies based on these (e.g. Svyatko et al. 2015, in press, Schulting et al. 2014, 2015; van der Plicht 2016). It has also been shown that FREs are present and appear highly variable in modern reservoirs across the area (Svyatko et al. current issue). However, to date, no specific FRE studies have been undertaken in Western Siberia. The problem of the presence of the freshwater reservoir effect has only been earlier discussed for the Bronze Age burial ground of Preobrazhenka 6 - the dates from human bone samples compared to those from charcoal and herbivore bone did not exclude the possibility of a 100 year offset (Marchenko et al. 2015).

Here, we attempted to assess the presence of the FRE in the area for the first time. The two associated samples from human and animal bone from burial 464 of Sopka 2/4B yielded a difference in ${ }^{14} \mathrm{C}$ ages of $87 \pm 67{ }^{14} \mathrm{C}$ years (Table 1) which is somewhat consistent with the offset from the Preobrazhenka 6 site and generally suggesting the possibility of apparent, older ${ }^{14} \mathrm{C}$ dates for the human individuals from the Baraba forest-steppe.

\section{The ${ }^{14} \mathrm{C}$ dates of the Seima-Turbino complexes in Eurasia}

Radiocarbon dates from Rostovka and Baraba forest-steppe burials on one hand and the Upper Ob River valley (Altai Region) necropoleis on another coincide in the period of $22^{\text {nd }}-20^{\text {th }} \mathrm{c}$. cal BC (Table 1, Figure 4). Dates from Teleutskii Vzvoz 1 and Eluninio 1 (Upper Ob River) are closer to those from Rostovka. The date OxA-12529 from Trans-Urals burial ground of Satyga 16 belongs to the same period (Hanks et al. 2007). The radiocarbon dates from Middle Volga River valley are more dispersed. The date from Pepkinskii Kurgan grave 2 (Ki-7665) is the oldest $-26^{\text {th }}-21^{\text {st }}$ c. cal BC (Kuznetsov 2003). Other three dates from Ust'-Vetluga cemetery (Hela-929, -966, -928) are younger $-21^{\text {st }}-17^{\text {th }}$ c. cal BC, and two of them (Hela-966, -928) have even younger age of $19^{\text {th }}-16^{\text {th }}$ c. cal BC. Surely, these data is not sufficient for resolving the issue of the Abashevo Culture chronology and chronology of the mixed Abashevo and ST complexes, however, the existing dates suggest that materials from Pepkinskii Kurgan are synchronous to the major ST sites, whereas items from Ust'-Vetluga are somewhat younger. Perhaps the latter 
reflect the final stage of the ST transcultural phenomenon. The date SOAN-1893 from Elunino 1 (Upper Ob River) $-21^{\text {st }}-18^{\text {th }} \mathrm{c}$ cal BC - takes an intermediate position between the dates from Ust'-Vetluga and other European and Asian ST complexes (Kiryushin 1987). Until the new radiocarbon and archaeological evidence is available, the chronology of this site cannot be precisely associated with neither main ST group complexes nor to the later Ust'-Vetluga site. As such, with the exception of dates from Ust'-Vetluga, all other necropoleis (in Eastern Europe, Trans Urals and Western Siberia) with the ST metal date to the $22^{\text {nd }}-20^{\text {th }}$ c. cal BC.

First ${ }^{14} \mathrm{C}$ dates for daggers with figured handles from Sopka 2/4B allowed defining their chronology and their place among the Bronze Age archaeological complexes. Earlier, some researchers attributed them to the circle of ST bronze items (Molodin 1993, Parzinger 2000, Grushin 2009, Kovtun 2013). Others brought parallels to the metallurgy of the Karasuk Culture of the Minusinsk basin (Sothern Siberia; Chlenova 1976, Papin and Fedoruk 2009). However, the Karasuk Culture has been recently dated to the $14^{\text {th }}-10^{\text {th }}$ c. cal BC (Goersdorf et al. 2001, Svyatko et al. 2009). Therefore, the two dates from Sopka $2 / 4 B$ (UBA-27424 $-26^{\text {th }}-23^{\text {th }}$ c. cal BC, and UBA-25206 $-24^{\text {th }}-21^{\text {nd }}$ c. cal BC) rather support the idea of synchroneity of daggers with figured handles and ST objects. The obtained ${ }^{14} \mathrm{C}$ dates for the daggers attribute them to not later than $3^{\text {rd }}$ mil. $\mathrm{BC}$, and at the same time there is no archaeological evidence to consider them earlier than the ST bronze objects.

In spite of apparent synchroneity of the ST objects and daggers with figure handles, it would be prematurely to consider these two bronze type objects as originating at the same metallurgical center, as they have different distribution areas. Seima-Turbino items have mainly been recovered from forest and forest-steppe zone of Eastern Europe and Western Siberia, whereas daggers with figured handles - from Central Asia. At the moment, forest-steppe and steppe zone of Ob-Irtysh region and Northern and Western Sayan-Altai mountains are regarded as their common area of distribution. We can suggest that in last third of the $3^{\text {rd }}$ mil. $\mathrm{BC}$, certain groups of warriors were moving from south and south-eastern regions of Central Asia through the ObIrtysh Interfluve, which was marked by findings of bronze warfare objects. The defined synchroneity of bronze objects, most likely produced in different metallurgical centers, indicates the accumulation of specialized bronze weapons in the south of Western Siberia in last third of the $3^{\text {rd }}$ - transition to the $2^{\text {nd }}$ mil. BC. Most probably, this region became the area of formation of the so-called "Siberian phalanx" military units (by P.M. Kozhin 1993) for long-distance western campaigns. The aim and the most likely enemy of the Siberian units were the Abashevo Culture population of the Volga-Urals region and, somewhat later, the Sintashta people of southern Urals (Chernykh and Kuzminykh 1987, Grigoriev 2002, Solovyov 2005, Bolshov 2012, Chernykh 2015). Currently, radiocarbon dates of the majority of Abashevo sites in the Volgo-Ural region belong to the $23^{\text {rd }}-19^{\text {th }}$ c. cal BC (Chernykh and Orlovskaya 2013, Molodin et al. 2014), with several sites in the Middle Don River basin dating to a younger period of $20^{\text {th }}-18^{\text {th }} \mathrm{c}$. cal BC (Shishlina et al. 2015). The Sintashta culture radiocarbon dates to the $21^{\text {st }}-18^{\text {th }}$ c. cal BC (Hanks et al. 2007, Molodin et al. 2014). As such, the obtained set of ${ }^{14} \mathrm{C}$ dates on the ST complexes from the south of Western Siberia allows the new level of synchronizing of the historical processes in the East European, South Ural and Western Siberian sites. 


\section{CONCLUSIONS}

The first set of radiocarbon dates from the Baraba forest-steppe and Middle Irtysh River region burial complexes confirmed their earlier age of the Seima-Turbino objects relatively to the traditional archaeological chronology based on Balkan and Chinese analogies. Previously, the objects were attributed to the $16^{\text {th }}-15^{\text {th }}$ c. BC (Chernykh 1992), while the new set of ${ }^{14} \mathrm{C}$ dates suggests $22^{\text {nd }}-20^{\text {th }}$ c. cal BC as the timing for the majority of sites with the Seima-Turbino items in Eastern Europe, Trans-Urals and south of Western Siberia. Presently, this is largest series of ${ }^{14} \mathrm{C}$ dates of the ST complexes in Eurasia. At the moment we can suggest that a number of ${ }^{14} \mathrm{C}$ dates from human bone samples from the Baraba forest-steppe are affected by the freshwater reservoir offset and appear older. Further research into freshwater reservoir offsets in the region is essential for the more reliable reconstruction of chronology of the Seima-Turbino phenomenon.

The analysed daggers with figured handles appear synchronous to the Seima-Turbino objects. Perhaps, the new discoveries and investigation of the similar complexes in Eurasia, and further ${ }^{14} \mathrm{C}$ dating will allow a more detailed chronology of the sites containing Seima-Turbino objects to be developed. At the moment, the ${ }^{14} \mathrm{C}$ dates from the Trans-Urals and south of Western Siberia, with the exception of the date from Elunino 1, attribute these complexes to not later than $3^{\text {rd }}$ mil. BC. The ${ }^{14} \mathrm{C}$ dates of ST metal objects from Eastern European sites currently appear younger than those from the Trans-Ural and Western Siberian ST sites, which is consistent with the common opinion suggesting that Seima-Turbino transcultural phenomenon expanded from the northern areas of Central Asia and Siberia to the west.

\section{ACKNOWLEDGEMENTS}

The paper was supported by the Russian Science Foundation (grant RSF-14-50-00036) and the Leverhulme Trust (grant RPG-2014-08).

\section{REFERENCES}

Alekhin YP, Vladimirov VN. 1984. Razvedochnye raboty v Predgornom Altae [Exploration work in the Altai foothill]. In: Arkheologicheskie otkrytiya 1982 goda. M.: Nauka Publishing. p 189-90. In Russian.

Bolshov SV. 2012. A contribution to the study of the Eastern Links of the Bronze Age culture of the Northern Middle Volga. Archaeology, Ethnology and Anthropology of Eurasia 1(40): 108-13.

Bronk Ramsey C. 1995. Radiocarbon calibration and analysis of stratigraphy: the OxCal program. Radiocarbon 37(2):425-30.

Bronk Ramsey C. 2001. Development of the radiocarbon calibration program OxCal. Radiocarbon. 43(2A):355-63.

Chernikov SS. 1960. Vostochnyi Kazakhstan v epokhu bronzy [Eastern Kazakhstan in the Bronze Age]. Materialy i Issledovaniya po Arkheologii SSSR 88. 272 p. In Russian. 
Cherhykh EN. 1970. Drevneishaya metallurgiya Urala i Povolzhya [Ancient Metallurgy of Urals and Volga River basin]. Materialy i Issledovaniya po Arkheologii SSSR 172. 180 p. In Russian.

Chernykh EN. 1992. Ancient Metallurgy in the USSR: The Early Metal Age. Cambridge: Cambridge University Press. 335 p.

Chernykh EN. 2009. Formation of Eurasian steppe belt cultures: Viewed through the lens of archaeometallurgy and radiocarbon dating. In: Hanks B, Lindoff K, editors. Social complexity in prehistoric Eurasia: Monuments, metals and mobility. Cambridge: Cambridge University Press. p 114-45.

Chernykh EN. 2015. Kochevoi mir Evrasii: nomady Zapada v kontse bronzovogo veka [Nomadic world of Eurasia: Western Nomads in the Late Bronze Age]. Pririoda 2. p 43-55. In Russian.

Chernykh EN, Kuzminykh SV. 1987. Pamyatniki Seimisko-Turbinskogo tipa v Evrazii [The Seima-Turbino type sites in Eurasia]. Epokha bronzy lesnoi polosy SSSR. Moscow: Nauka Publishing. 472 p. In Russian.

Chernykh EN, Orlovskaya LB. 2013. O baze dannykh kalendarnoi radiouglerodnoi khronologii «dopis'mennoi» epokhi kul'tur Zapadnoi Evrazii [About database of calendar radiocarbon chronology for «preliterate» age of cultures in Western Eurasia]. Analiticheskie issledovaniya Laboratorii estestvennonauchnyikh metodov. Vypusk 3. Moscow: IA RAN Publishing. p 8-15. In Russian.

Chlenova NL. 1976. Karasukskie kinzhaly [The Karasuk culture daggers]. Moscow: Nauka Publishing. 104 p. In Russian.

DeNiro MJ. 1985. Postmortem preservation and alteration of in vivo bone collagen isotope ratios in relation to palaeodietary reconstruction. Nature 317:806-9.

Görsdorf J, Parzinger H, Nagler A. 2001. New radiocarbon dates of the North Asian steppe zone and its consequences for the chronology. Radiocarbon 43(2B):1115-20.

Grigoriev SA. 2002. Ancient Indo-Europeans. Chelyabinsk: Rifei Publishing. 496 p.

Grushin SP. 2009. Altai v sisteme metallurgicheskikh provintsii eneolita i bronzovogo veka [Altai in the system metallurgical province of Eneolithic and Bronze Ages]. In: Grushin SP, Papin DV, Pozdnyakova OA, Tyurina EA, Fedoruk AS, Khavrin SV. Altai v sisteme metallurgicheskikh provintsii eneolita i bronzovogo veka. Barnaul: ASU Publishing: 122-31. In Russian.

Grushin SP, Merz VK, Papin DV, Peresvetov GY. 2006. Materialy epokhi bronzy iz Pavlodarskogo Priirtysh'ya [Bronze Age materials from the Pavlodar's Irtysh River basin]. In: Grushin SP, editor. Altai v sisteme metallurgicheskikh provintsii bronzovogo veka. Barnaul: ASU Publishing. p 4-17. In Russian.

Hanks BK, Epimakhov AV, Renfrew AC. 2007. Towards a Refined Chronology for the Bronze Age of the Southern Urals, Russia. Antiquity 81(312). p 353-67. 
Khalikov AH, Lebedinskaya GV, Gerasimova MM. 1966. Pepkinskii kurgan (abashevskii chelovek) [Pepkinskii Kurgan (Abashevo men)]. Ioshkar-Ola: Marknigizdat Publishing. 60 p. In Russian.

Kiryushin YF. 1987. Novye mogil'niki rannei bronzy na Verkhnei Obi [The new Bronze Age burial grounds from the Upper Ob River basin]. In: Kiryushin YF, editor. Arkheologicheskie issledovaniya na Altae. Barnaul: ASU Publishing. p 100-25. In Russian.

Kuryushin YF, Grushin SP. 2009. Early and Middle Bronze Age portable art pieces from the forest-steppe zone of the Ob-Irtysh region. Archaeology, Ethnology and Anthropology of Eurasia 4(37): 67-75.

Kiryushin YF, Grushin SP, Tishkin AA. 2003. Pogrebalnyi obryad naseleniya epokhi rannei bronzy Verkhnego Priob'ya (po materialam gruntovogo mogil'nika Teleutskii Vzvoz-1) [Burial rite practiced by Early Bronze Age population in the Upper Ob River basin (based on data resulted from the study of the Teleutsky Vzvoz 1 burial ground)]. Barnaul: ASU Publishing. 333 p. In Russian.

Kiryushin YF, Grushin SP, Tishkin AA. 2006. Sluchainye nakhodki bronzovykh predmetov v severo-zapadnykh predgor'yakh Altaia [Ocassional finds of bronze objects from northwestern part of Altai's foothills]. In: Grushin SP, editor. Altai v sisteme metallurgicheskikh provintsii bronzovogo veka. Barnaul: ASU Publishing. p 45-53. In Russian.

Kovalev AA. 2013. Novye dannye o svyazyakh kul'tur Zapadnoi Sibiri, Mongolii i Kitaya v pervoi polovine II tys. do n.e. [New evidence on the communications of cultures Western Siberia, Mongolia and China in first half of $2^{\text {nd }}$ Millenium BC]. In: Tishkin AA editor. Sovremennye resheniya aktual'nykh problem Evrasiiskoi arkheologii. Barnaul: ASU Publishing. p 140-6. In Russian.

Kovtun IV. 2012. Kon' $i$ lyzhik [Horse and skier]. Tomsk: TSU Publishing. Tom 4. 128 p. In Russian.

Kovtun IV. 2013. Predistoriya indoariiskoi mifologii [Prehistory of Indo-Aryan mythology]. Kemerovo: Aziya-Print Publishing. 702 p. In Russian.

Kozhin PM. 1993. Sibirskaya falanga epokhi bronzy [Siberian phalanx of Bronze Age]. In: Medvedev VE, Khudyakov YS, editors. Voennoe delo naseleniya yuga Zapadnoi Sibiri $i$ Dal'nego Vostoka. Novosibirsk: Nauka Publishing. p 16-41. In Russian.

Kuznetsov PF. 2003. K voprosu o khronoogii abashevskoi kul'tury [To question about chronology of Abashevo culture]. In: Bochkarev VS, Korenevskii SN, Kuznetsov PF, Kuz'mina OV, Munchaev RM, Petrovskaya MK, Pryakhin AD, Trofimov AA (eds.). Abashevskaya istoriko-kul'turnaya obshchnost': istoki, razvitie, nasledie. Cheboksary. p. 86-8. In Russian.

Marchenko ZV, Orlova LA, Panov VS, Zubova AV, Molodin VI, Pozdnyakova OA, Grishin AE, Uslamin EA. 2015. Paleodiet, radiocarbon chronology, and the possibility of fresh-water reservoir effect for Preobrazhenka 6 burial ground, Western Siberia: preliminary results. Radiocarbon 57(4). p 595-610. 
Matyushchenko VI, Sinitsyna GV. 1988. Mogil'nik u derevni Rostovka vblizi Omska [Ground burial around Rostovka settlement near Omsk city]. Tomsk: TSU Publishing: 136 p. In Russian.

Molodin VI. 1983. Pogrebenie liteishchika iz mogil'nika Sopka 2 [The tomb of a smelter at the burial site of Sopka 2]. In: Kiryushin YF, editors. Drevnie gornyaki i metallurgi Sibiri. Barnaul: ASU Publishing. p 96-109. In Russian.

Molodin VI. 1985. Baraba v epokhu bronzy [Baraba in the Bronze Age]. Novosibirsk: Nauka Publishing. 200 p. In Russian.

Molodin VI. 1993. Novyi vid bronzovykh kinzhalov v pogrebeniyakh krotovskoi kul'tury [New type of bronze dagger in the Krotovo culture graves]. In: Medvedev VE, Khudyakov YS, editors. Voennoe delo naseleniya yuga Zapadnoi Sibiri i Dal'nego Vostoka. Novosibirsk: Nauka Publishing. p 4-16. In Russian.

Molodin VI. 2001. Pamyatnik Sopka 2 na reke Omi. Kul'turno-khronlogicheskii analiz pogrebal'nykh kompleksov epokhi neolita i rannego metalla [The site of Sopka 2 on the Om River. Cultural and chronological analysis of the Neolithic and Early Metal Age burial complexes]. Tom 1. Novosibirsk: IAET SO RAN Publishing. 128 p. In Russian.

Molodin VI. 2012. Pamyatnik Sopka 2 na reke Omi. Kul'turno-khronlogicheskii analiz pogrebal'nykh kompleksov odinovskoi kul'tury [The site of Sopka 2 on the Om River. Cultural and chronological analysis of burial complexes associated with the Odino culture]. Tom 3. Novosibirsk: IAET SO RAN Publishing. 220 p.

Molodin VI, Chemyakina MA, Pozdnyakova OA. 2007. Arkheologo-geofizicheskie issledovaniya pamyatnika Preobrazhenka 6 v Barabinskoi lesostepi [Archaeo-geophysical studies carried out at the site of Preobrazhenka 6 in the Baraba forest-steppe]. In: Derevyanko AP, Molodin VI, editors. Problemy Arkheologii, Etnografii, Antropologii Sibiri i Sopredelnykh Territorii. Tom 13. Novosibirsk: IAET SO RAN Publishing. p 339-44. In Russian.

Molodin VI, Hansen S, Mylnikova LN, Nagler A, Kobeleva LS, Durakov IA, Efremova NS, Novikova OI, Nesterova MS, Nenakhov DA, Kovyrshina YN, Mosechkina NN, Vasil'eva YA. 2011. Arkheologicheskie issledovaniya mogil'nika Tartas 1 v 2011 godu: osnovnye resul'taty [Archaeological researches on the burial Tartas 1 in 2011 year: basic results]. In: Derevyanko AP, Molodin VI, editors. Problemy arkheologii, etnografii, antropologii Sibiri $i$ sopredel'nykh territorii. Tom 17. Novosibirsk: IAET SO RAN Publishing. p 206-11. In Russian.

Molodin VI, Marchenko ZV, Grishin AE, Orlova LA. 2010. Novye dannye po radiouglerodnoi khronologii pogrebal'nykh kompleksov mogil'nika Sopka 2 epokhi rannei-razvitoi bronzy [New data on radiocarbon chronology of funerary complexes associated with the Early and Middle Bronze Age burial site of Sopka 2]. In: Dervyanko AP, Molodin VI, editors. Problemy arkheologii, etnografii, antropologii Sibiri i sopredel'nykh territorii. Tom. 16. Novosibirsk: IAET SO RAN Publishing. p 240-6. In Russian. 
Molodin VI, Marchenko ZV, Kuzmin YV, Grishin AE, Van Strydonck M, Orlova LA. 2012. Radiocarbon chronology of burial grounds of the Andronovo Period (Middle Bronze Age) in Baraba Forest Steppe, western Siberia. Radiocarbon 54(3-4). P 737-47.

Molodin VI, Mylnikova LN, Durakov IA, Borzykh KA, Selin DV, Nesterova MS, Kovyrshina YN. 2015. Proyavlenie seiminsko-turbinskogo fenomena na poselenii krotovskoi kul'tury Vengerovo 2 (Barabiskaya lesostep') [Manifestation of Seima-Turbino phenomenon on the Krotovo culture settlement Vengerovo 2 (Baraba forest-steppe)]. In: Derevyanko AP, Molodin VI, editors. Problemy arkheologii, etnografii, antropologii Sibiri i sopredel'nykh territorii. Tom 21. Novosibirsk: IAET SO RAN Publishing. p 321-5. In Russian.

Molodin VI, Sofeikov OV, Deich BA, Grishin AE, Chemyakina MA, Manshtein AK, Balkov EV, Shatov AG. 2003. Novyi pamayatnik epokhi bronzy v Barabinskoi lesostepi (mogil'nik Tartas 1) [New Bronze Age site in Baraba forest-steppe (burial ground Tartas 1)]. In: Derevyanko AP, Molodin VI, editors. Problemy arkheologii, etnografii, antropologii Sibiri $i$ sopredel'nykh territorii. Tom 9, chast 1. Novosibirsk: IAET SO RAN Publishing. p 441-6. In Russian.

Papin DV, Fedoruk AS. 2009. Pozdnii period bronzovogo veka i perekhodnoe vremya ot bronzovogo k rannemu zheleznomu veku [The Late Bronze Age and transition period from Bronze to Early Iron Age]. In: Grushin SP, Papin DV, Pozdnyakova OA, Tyurina EA, Fedoruk AS, Khavrin SV. Altai v sisteme metallurgicheskikh provintsii eneolita $i$ bronzovogo veka. Barnaul: ASU Publishing: p 75-121. In Russian.

Parzinger G. 2000. Seiminsko-Turbinskii phenomen i formirovanie sibirskogo zverinnogo stilya. Arkheologiya, Etnographiya i Antropologiya Evrazii. 1(1). p 66-75. In Russian.

Reimer PJ, Baillie MGL, Bard E, Bayliss A, Beck JW, Bertrand CJH, Blackwell PG, Buck CE, Burr GS, Cutler KB, Damon PE, Edwards RL, Fairbanks RG, Friedrich M, Guilderson TP, Hogg AG, Hughen KA, Kromer B, McCormac G, Manning S, Bronk Ramsey C, Reimer RW, Remmele S, Southon JR, Stuiver M, Talamo S, Taylor FW, van der Plicht J, Weyhenmeyer CE. 2004. IntCal04 terrestrial radiocarbon age calibration, 0-26 cal kyr BP. Radiocarbon 46(3). p 1029-58.

Samashev ZS, Zhumabekova G. 1993. K voprosu o kul'turnoi atribitsii nekotorykh sluchainykh nakhodok iz Kazakhstana [To issue about cultural attribution of some case findings from Kazakhstan]. In: Izvestiya Natsional'noi Akademii Nauk Respubliki Kazakhstan. Seriya Obshchestvennye nauki. Almaty: Gylym Publishing. 5(191). P 23-33. In Russian.

Schulting R, Ramsey CB, Bazaliiskii VI, Goriunova OI, Weber A. 2014. Freshwater Reservoir Offsets Investigated through Paired Human-Faunal ${ }^{14} \mathrm{C}$ Dating and Stable Carbon and Nitrogen Isotope Analysis at Lake Baikal, Siberia. Radiocarbon 56: 991-1008.

Schulting RJ, Bronk Ramsey C, Bazaliiskii VI, Weber A. 2015. Highly Variable Freshwater Reservoir Effects Found along the Upper Lena Watershed, Cis-Baikal, Southeast Siberia. Radiocarbon 57(4): 581-93.

Shishlina NI, Skorobogatov AM, Kaiser E, Usachuk AN. 2015. Radiouglerodnoe datirovanie parnykh obraztsov iz mogil'nika Rozhdestveno: rezul'taty analiza i obsuzhdenie 
[Radiocarbon dating paired samples from burial ground Rozhdestveno: results and discussion]. Izvestiya Samarskogo nauchnogo tsentra Possiiskoi Akakdemii Nauk 17(3). P 262-272. In Russian.

Solovyov BS. 2003. Ob abashevskom komponente Yurinskogo mogil'nika [About Abashevo component of Yurino necropolis]. In: Bochkarev VS, Korenevskii SN, Kuznetsov PF, Kuz'mina OV, Munchaev RM, Petrovskaya MK, Pryakhin AD, Trofimov AA, editors. Abashevskaya istoriko-kul'turnaya obshchnost': istoki, razvitie, nasledie. Cheboksary. $\mathrm{p}$ 188-92. In Russian.

Solovyov BS. 2005. Yurinskii (Ust'-Vetluzhskii) mogil'nik (itogi raskopok 2001-2004 gg.) [Yurino (Ust'-Vetluga) burial ground (results excavations of 2001-2004 years)]. Rossiiskaya arkheologiya 4:103-12. In Russian.

Solovyov BS. 2013. Kul'turnye komponenty Ust'-Vetluzhskogo mogil'nika [Cultural components of Ust'-Vetluga burial ground]. Povolzhskaya arkheoogiya 2(4):18-39. In Russian.

Svyatko SV, Mallory JP, Murphy EM, Polyakov AV, Reimer PJ, Schulting RJ. 2009. New radiocarbon dates and a review of the chronology of prehistoric populations from the Minusinsk basin, Southern Siberia, Russia. Radiocarbon 51(1). p 243-73.

Svyatko SV, Mertz IV, Reimer PJ. 2015. Freshwater Reservoir Effect on Redating of Eurasian Steppe Cultures: First Results for Eneolithic and Early Bronze Age Northeast Kazakhstan. Radiocarbon 57(4): 625-44.

Svyatko SV, Schulting R, Poliakov A, Reimer PJ (in press) A lack of freshwater reservoir effects in human radiocarbon dates in the Eneolithic to Iron Age in the Minusinsk Basin. Radiocarbon.

Trufanov AY (ed.). 2011. Satyga 16 - seiminsko-turbinskii mogil'nik v taezhnoi zone Zapadnoi Sibiri [Satyga 16 - Seima-Turbino necropolis in forest zone of Western Siberia]. Ekaterinburg: Uralskii rabochiy Publishing. 192 p. In Russian.

van der Plicht J, Shishlina NI, Zazovskaya EP. 2016. Radiocarbon dating: Chronology of archaeological cultures and the reservoir effect. Moscow: Buki Vedi Publishing. 112 p. In Russian.

van Klinken GJ. 1999. Bone Collagen Quality Indicators for Palaeodietary and Radiocarbon Measurements. Journal of Archaeological Science 26(6):687-95.

Vinnik DF, Kuz'mina EE. 1981. Vtoroi Karakol'skii klad Kirgizii [The Second Karakol Hoard in Kyrgyzstan]. Kratkie soobshcheniya Instituta Arkheologii 167:48-53. In Russian.

Yunger H., Karpelan K. 2005. O radiouglerodnyikh datakh Ust'-Vetluzhskogo mogil'nika [On radiocarbon dates produced for the burial site of Ust-Vetluzhsky]. Rossiiskaya Arkheologiya 4. p. 112. In Russian. 


\section{Figure captions}

Figure 1. Map showing the distribution of the Seima-Turbino objects (circles for occasional and single finds and rectangles for funeral and ritual-funeral complexes) and daggers with figure handles (triangle indicate complexes and occasional finds) in Eurasia. Seima-Turbino sites: 1 Seima, 2 - Reshnoe, 3 - Ust'-Vetluga, 4 - Pepkinskii Kurgan and Turbino, 5 - Kaninskaya cave, 6 - Satyga 16, 7 - Shaitanskoe 2, 8 - Rostovka, 9 - Tartas 1, Sopka 2/4B and Sopka 2/4C, 10 Preobrazhenka 6,11- Elunino 1 and Teleutskii Vzvoz 1. Complexes containing daggers with figure handles: 9 - burial ground Sopka 2/4B, 12 - the Second Karakol Hoard. Map sources: Chernykh 2015, Chlenova 1976, Alekhin and Vladimirov, 1984, Molodin 1983, 1993, Samashev and Zumabekova, 1993, Grushin et al. 2006, Kiryushin et al. 2006, Molodin et al. 2007, 2011, Kovalev 2013.

Figure 2. Seima-Turbino objects (4,5 - stone, other - bronze) in the burial grounds from the south of Western Siberia. 1, 3, 9, 10 - Rostovka (Matyushchenko and Sinitsyna 1988); 2 Elunino 1 (Kiryushin 1987); 4-6 - Sopka 2/4C (Molodin 1983); 7 - Tartas 1 (Molodin et al. 2011), 8 - Preobrazhenka 6 (Molodin et al. 2007).

Figure 3. Bronze daggers with figure handles from Sopka 2/4B burial ground and their analogies. 1-5 - the Second Karakol Hoard (Vinnik and Kuz'mina 1981), 9-11 - Sopka 2/4B (Molodin 1993), other - occasional finds. 6, 7 - Eastern Kazakhstan (Samashev and Zumabekova, 1993), 8 - Altai (Kiryushin et al. 2006), 12 - Upper Irtysh River basin (Grushin et al. 2006), 13, 14 province Gansu (Kovalev 2013), 15 - Southern Siberia (Chlenova 1976), 16 - Altai (Alekhin and Vladimirov 1984), 17 - Altai (Chlenova 1976), 18, 21 - Kazakhstan (Chlenova 1976), 19 Kazakhstan (Chernikov 1960), 20 - Altai or Kazakhstan (Chlenova 1976). 15-21 are without scale.

Figure 4. Plotted calibrated radiocarbon dates (from current and published research - see Table 1) of the Seima-Turbino sites: 1- Middle Irtysh River basin, 2 - Baraba forest-steppe, 3 - Upper Ob River basin, 4 - Trans-Urals, 5 - Middle Volga River basin.

\section{Table caption}

Table 1. Radiocarbon dates, calibrated ages and stable isotope values for the Seima-Turbino complexes of Eurasia (from current and previous research). Sk. - skeletal. ${ }^{1}$ Marchenko et al., 2015, ${ }^{2}$ Kuryushin et al. 2003, ${ }^{3}$ Kiryushin et al. 1987, ${ }^{4}$ Hanks et al. 2007, ${ }^{5}$ Yunger and Karpelan 2005, ${ }^{6}$ Kuznetsov 2003 


\begin{tabular}{|c|c|c|c|c|c|c|c|c|c|}
\hline Site & Burial & Lab. Code & ${ }^{14} \mathrm{C}, \mathrm{BP}$ & Material & $\begin{array}{l}\text { Cal. age, } \\
\text { BC }(2 \sigma)\end{array}$ & $\begin{array}{c}\delta^{13} \mathrm{C} \\
\% 0\end{array}$ & $\begin{array}{l}\delta^{15} \mathrm{~N} \\
\%\end{array}$ & $\begin{array}{c}\mathrm{C}: \mathrm{N}_{\mathrm{a}} \\
\mathrm{t}\end{array}$ & $\begin{array}{c}\% \\
\text { colla } \\
\text { gen } \\
\end{array}$ \\
\hline \multirow[t]{11}{*}{ Rostovka } & 5 & UBA-31379 & $3508 \pm 40$ & $\begin{array}{l}\text { human bone } \\
\text { (craneo) }\end{array}$ & $1938-1700$ & -20.6 & 13.6 & 3.24 & 4.8 \\
\hline & 5 & UBA-31396 & $3682 \pm 40$ & human tooth (uM3) & 2197-1951 & -20.0 & 14.5 & 3.18 & 11.3 \\
\hline & $\begin{array}{c}8, \text { sk. } \\
4\end{array}$ & UBA-31381 & $3709 \pm 34$ & $\begin{array}{l}\text { human bone } \\
\text { (vertebra) }\end{array}$ & $2202-1983$ & -21.1 & 14.7 & 3.21 & 5.4 \\
\hline & $\begin{array}{c}8, \text { sk. } \\
4\end{array}$ & UBA-31398 & $3708 \pm 30$ & $\begin{array}{l}\text { human tooth (I } \\
\text { M3) }\end{array}$ & $2200-2023$ & -19.0 & 16.8 & 3.20 & 10.6 \\
\hline & 23 & UBA-29311 & $3822 \pm 32$ & $\begin{array}{l}\text { human bone } \\
\text { (temporal) }\end{array}$ & $2455-2144$ & -20.8 & 13.5 & 3.15 & 4.7 \\
\hline & 24 & UBA-29313 & $3564 \pm 38$ & human tooth (M2) & $2054-1774$ & -20.5 & 12.7 & 3.22 & 14.8 \\
\hline & 27 & UBA-31383 & $3655 \pm 40$ & $\begin{array}{l}\text { human bone } \\
\text { (craneo) }\end{array}$ & 2141-1918 & -20.8 & 14.0 & 3.20 & 6.7 \\
\hline & 27 & UBA-31399 & $3635 \pm 40$ & human tooth (IM3) & $2135-1896$ & -20.1 & 13.1 & 3.20 & 12.5 \\
\hline & 33 & UBA-31382 & $3640 \pm 31$ & $\begin{array}{l}\text { human bone } \\
\text { (craneo) }\end{array}$ & 2133-1919 & -21.2 & 14.6 & 3.21 & 10.7 \\
\hline & 34 & UBA-31380 & $3646 \pm 39$ & $\begin{array}{l}\text { human bone } \\
\text { (vertebra) }\end{array}$ & 2137-1919 & -20.4 & 13.7 & 3.19 & 7.5 \\
\hline & 34 & UBA-31397 & $4066 \pm 50$ & $\begin{array}{l}\text { human tooth (ur } \\
\text { M3) }\end{array}$ & $2862-2473$ & -20.8 & 14.1 & 3.19 & 9.2 \\
\hline Staryi Tartas & - & UBA-27417 & $3834 \pm 31$ & wood & $2456-2200$ & - & - & - & - \\
\hline \multirow[t]{5}{*}{ Sopka 2/4B } & 420 & UBA-27424 & $3917 \pm 38$ & human bone & $2559-2289$ & -19.7 & 14.3 & 3.17 & 14.9 \\
\hline & 425 & UBA-25026 & $3784 \pm 40$ & human bone & $2388-2042$ & -22.4 & 15.4 & 3.20 & 15.8 \\
\hline & 427 & UBA-25027 & $3787 \pm 31$ & human bone & $2335-2063$ & -21.1 & 13.1 & 3.15 & 17.7 \\
\hline & 464 & SOAN-8269 & $3730 \pm 35$ & $\begin{array}{l}\text { human bone } \\
\text { (Femur Dx) }\end{array}$ & $2276-2028$ & - & - & - & - \\
\hline & 464 & UBA-29748 & $3643 \pm 57$ & Ovis bone & $2198-1883$ & -19.4 & 6.7 & 3.27 & 4.6 \\
\hline \multirow[t]{4}{*}{ Sopka 2/4C } & 282 & SOAN-7725 & $3805 \pm 75$ & $\begin{array}{l}\text { human bone (Tibia } \\
\text { Sin, Femur Sin) }\end{array}$ & $2467-2036$ & - & - & - & - \\
\hline & 594 & SOAN-7718 & $3850 \pm 105$ & $\begin{array}{l}\text { human bone } \\
\text { (Femur Sin) }\end{array}$ & 2581-1980 & - & - & - & - \\
\hline & 594 & UBA-25028 & $3712 \pm 32$ & human bone & $2202-2024$ & -21.4 & 14.1 & 3.19 & 25.2 \\
\hline & 623 & UBA-25029 & $3661 \pm 34$ & human bone & $2139-1943$ & -22.3 & 14.2 & 3.29 & 12.7 \\
\hline \multirow[t]{2}{*}{ Tartas 1} & 487 & UBA-27422 & $3811 \pm 61$ & human bone & 2464-2050 & -20.7 & 13.1 & 3.15 & 12.1 \\
\hline & 487 & SOAN-8703 & $3935 \pm 85$ & $\begin{array}{c}\text { human bone } \\
\text { (Femur Sin, Femur } \\
\text { Dx) }\end{array}$ & $2836-2145$ & - & - & - & - \\
\hline Preobrazhenka 6 & 24 & UBA-25804 ${ }^{1}$ & $3797 \pm 29$ & human bone & $2336-2138$ & -20.7 & 13.7 & 3.21 & 2.2 \\
\hline \multirow{4}{*}{$\begin{array}{c}\text { Teleutskii Vzvoz } \\
1\end{array}$} & 10 & SOAN-41532 & $3690 \pm 40$ & charocoal & $2199-1960$ & - & - & - & - \\
\hline & 12 & SOAN-4154 2 & $3650 \pm 75$ & charocoal & $2278-1777$ & - & - & - & - \\
\hline & 32 & SOAN-4369 & $3610 \pm 35$ & charocoal & $2120-1885$ & - & - & - & - \\
\hline & 34 & SOAN $-4370^{2}$ & $3670 \pm 40$ & charocoal & 2195-1939 & - & - & - & - \\
\hline Elunino 1 & 2 & SOAN- $1893^{3}$ & $3560 \pm 30$ & charocoal & 2016-1775 & - & - & - & - \\
\hline Satyga 16 & 39 & OxA-12529 & $3655 \pm 29$ & human bone & 2135-1944 & - & - & - & - \\
\hline \multirow[t]{3}{*}{ Ust-Vetluga } & 8 & Hela- $929^{5}$ & $3545 \pm 50$ & wood & $2023-1747$ & - & - & - & - \\
\hline & 10 & Hela- $966^{5}$ & $3395 \pm 35$ & wood & $1862-1614$ & - & - & - & - \\
\hline & 12 & Hela- $928^{5}$ & $3400 \pm 50$ & wood & $1879-1560$ & - & - & - & - \\
\hline $\begin{array}{l}\text { Pepkinskii } \\
\text { Kurgan }\end{array}$ & 2 & Ki-7665 & $3850 \pm 95$ & human bone & $2570-2035$ & - & - & - & - \\
\hline
\end{tabular}




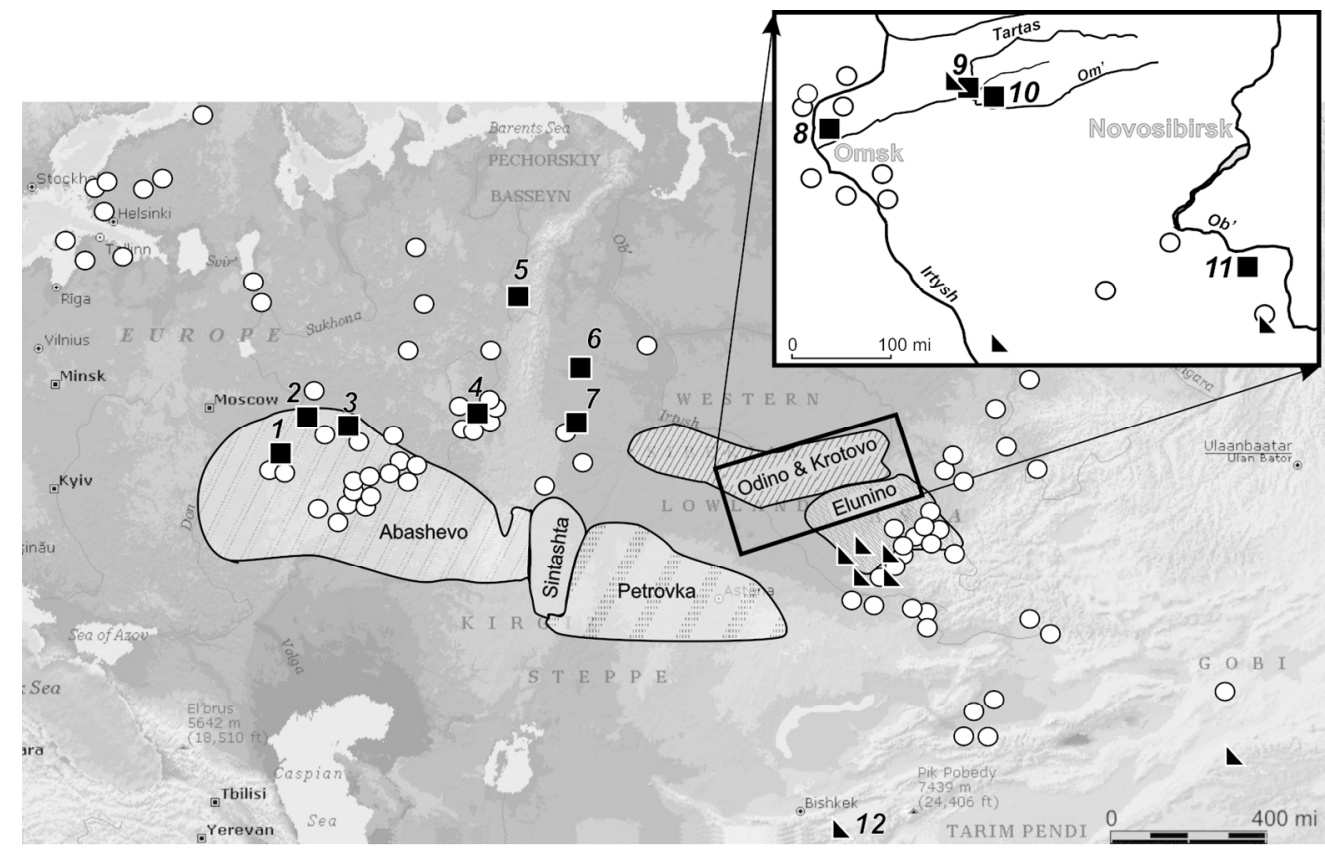

Figure 1. Map showing the distribution of the Seima-Turbino objects (circles for occasional and single finds and rectangles for funeral and ritual-funeral complexes) and daggers with figure handles (triangle indicate complexes and occasional finds) in Eurasia. Seima-Turbino sites: 1 - Seima, 2 - Reshnoe, 3 - Ust'-Vetluga, 4 - Pepkinskii Kurgan and Turbino, 5 - Kaninskaya cave, 6 - Satyga 16, 7 - Shaitanskoe 2, 8 - Rostovka, 9 - Tartas 1, Sopka 2/4B and Sopka 2/4C, 10 - Preobrazhenka 6, 11 - Elunino 1 and Teleutskii Vzvoz 1. Complexes containing daggers with figure handles: 9 - burial ground Sopka 2/4B, 12 - the Second Karakol Hoard. Map sources: Chernykh 2015, Chlenova 1976, Alekhin and Vladimirov, 1984, Molodin 1983, 1993, Samashev and Zumabekova, 1993, Grushin et al. 2006, Kiryushin et al. 2006, Molodin et al. 2007, 2011, Kovalev 2013.

$140 \times 89 \mathrm{~mm}(300 \times 300$ DPI $)$ 


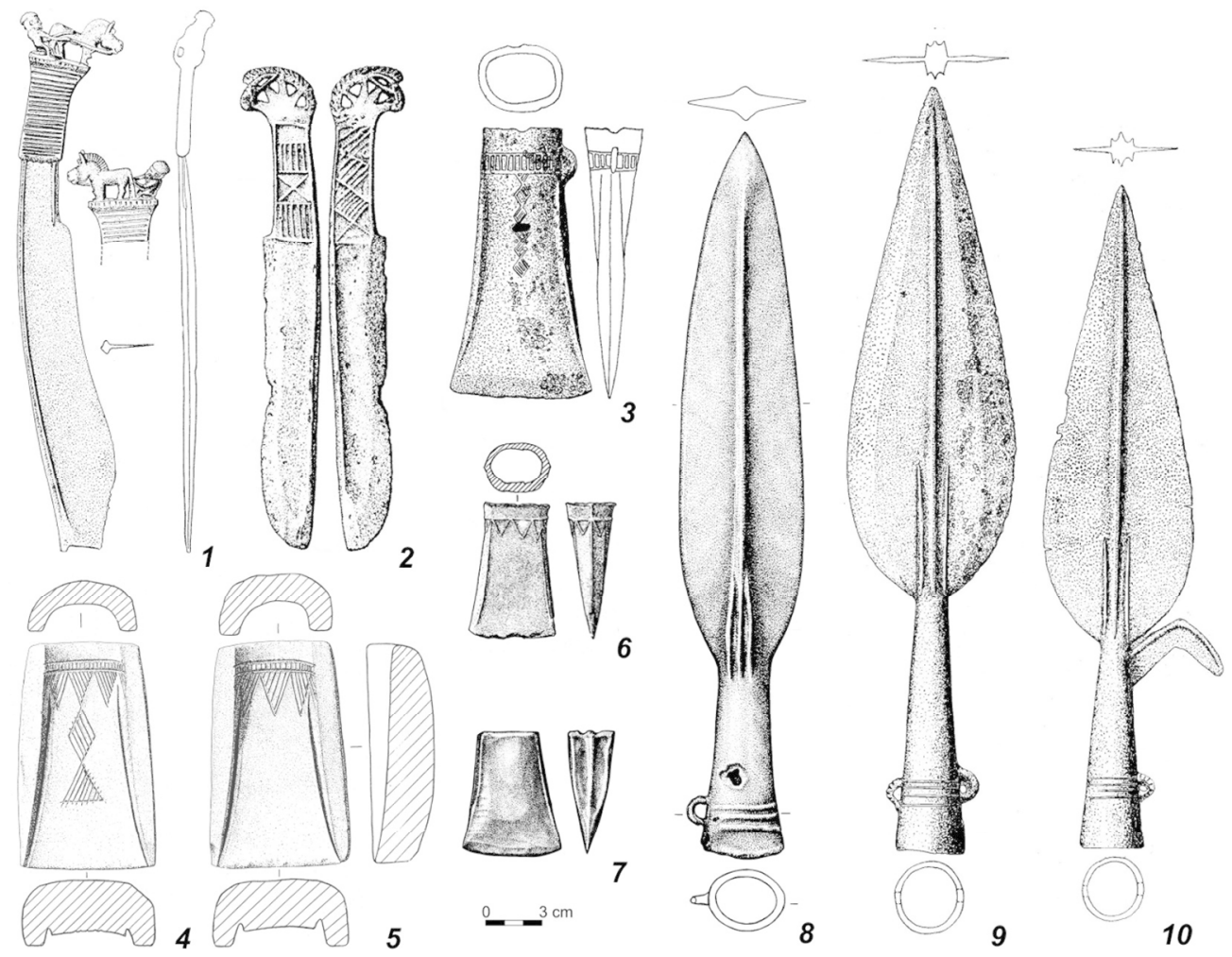

Figure 2. Seima-Turbino objects (4,5 - stone, other - bronze) in the burial grounds from the south of Western Siberia. 1, 3, 9, 10 - Rostovka (Matyushchenko and Sinitsyna 1988); 2 - Elunino 1 (Kiryushin 1987); 4-6 - Sopka 2/4C (Molodin 1983); 7 - Tartas 1 (Molodin et al. 2011), 8 - Preobrazhenka 6 (Molodin et al. 2007).

$140 \times 107 \mathrm{~mm}(300 \times 300 \mathrm{DPI})$ 


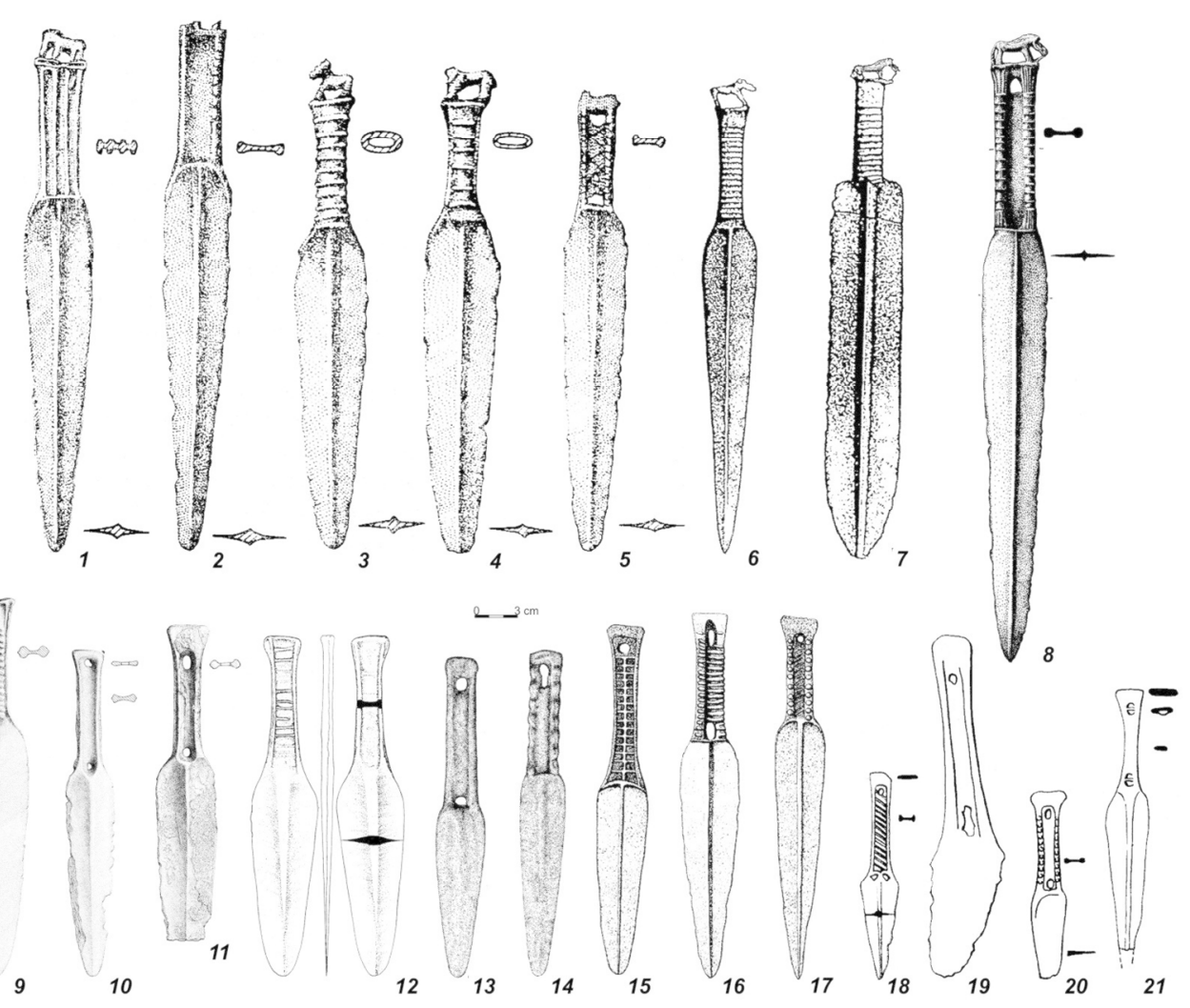

Figure 3. Bronze daggers with figure handles from Sopka 2/4B burial ground and their analogies. 1-5 - the Second Karakol Hoard (Vinnik and Kuz'mina 1981), 9-11 - Sopka 2/4B (Molodin 1993), other - occasional finds. 6, 7 - Eastern Kazakhstan (Samashev and Zumabekova, 1993), 8 - Altai (Kiryushin et al. 2006), 12 Upper Irtysh River basin (Grushin et al. 2006), 13, 14 - province Gansu (Kovalev 2013), 15 - Southern Siberia (Chlenova 1976), 16 - Altai (Alekhin and Vladimirov 1984), 17 - Altai (Chlenova 1976), 18, 21 Kazakhstan (Chlenova 1976), 19 - Kazakhstan (Chernikov 1960), 20 - Altai or Kazakhstan (Chlenova 1976). $15-21$ are without scale.

$139 \times 111 \mathrm{~mm}(300 \times 300 \mathrm{DPI})$ 
OxCal v4.2.4 Bronk Ramsey (2013); r:5 IntCal13 atmospheric curve (Reimer et al 2013)

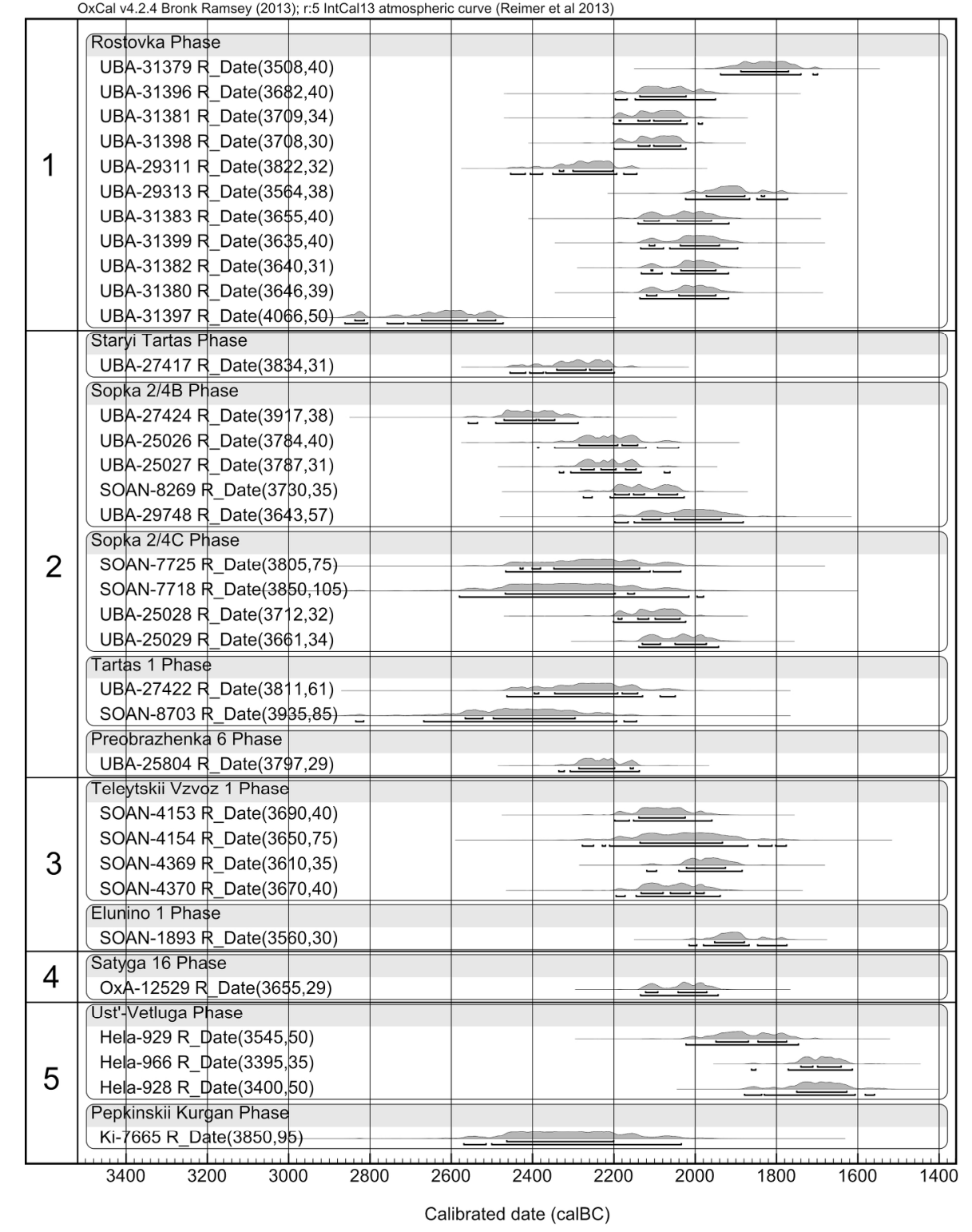

Figure 4. Plotted calibrated radiocarbon dates (from current and published research - see Table 1) of the Seima-Turbino sites: 1- Middle Irtysh River basin, 2 - Baraba forest-steppe, 3 - Upper Ob River basin, 4 Trans-Urals, 5 - Middle Volga River basin.

$199 \times 260 \mathrm{~mm}(300 \times 300 \mathrm{DPI})$ 